\title{
Sasanian copper and billon coins from the collections of the Royal Museums of Art and History, Brussels, Belgium-insights using semi-quantitative analysis by $\mu \mathrm{XRF}$
}

\author{
A. Van Ham-Meert ${ }^{1,2}$ (D) F. W. Rademakers ${ }^{1} \cdot$ R. Gyselen ${ }^{3} \cdot$ B. Overlaet ${ }^{4} \cdot$ P. Degryse $^{1,5} \cdot$ P. Claeys $^{2}$
}

Received: 19 May 2020 / Accepted: 4 September 2020 / Published online: 21 September 2020

(C) Springer-Verlag GmbH Germany, part of Springer Nature 2020

\begin{abstract}
This paper presents the micro-XRF analysis of over 100 Sasanian billon and copper coins from the collections of the Royal Museums of Art and History in Brussels, Belgium. This study discovered that some coins, thought to be copper, were actually billon coins. Furthermore, it illustrated the continuity in use and recipe of small copper coins from the Parthian into the Sasanian period. Previous research into the elemental composition of copper coins from the Sasanian period only spanned the period 224$309 \mathrm{CE}$, while this paper encompasses the whole period until the fall of the empire in $651 \mathrm{CE}$. The link with lead coins is also discussed.
\end{abstract}

Keywords Sasanian coins $\cdot \mathrm{XRF} \cdot \mathrm{Cu}$ alloys

\section{Introduction}

\section{General introduction}

The present paper is concerned with the study of copper and billon (silver-copper alloy) coins from the Sasanian period. As such, it builds on previous research concerning lead coins from the Sasanian period (Van Ham-Meert et al. 2018).

Electronic supplementary material The online version of this article (https://doi.org/10.1007/s12520-020-01191-2) contains supplementary material, which is available to authorized users.

A. Van Ham-Meert

alicia.vanhammeert@kuleuven.be; alicia.vanhammeert@gmail.com

1 Earth and Environmental Science, Division of Geology, KULeuven, Heverlee, Belgium

2 Analytical, Environmental and Geo-Chemistry, VUB, Brussels, Belgium

3 Centre de Recherche sur le Monde Iranien, CNRS, Ivry-sur-Seine, France

4 Ancient Near East and Iran, Royal Museums of Art and History, Brussels, Belgium

5 Faculty of Archaeology, Archaeological Sciences, Universiteit Leiden, Leiden, Netherlands
The Sasanian Empire superseded the Parthian Empire (centred around modern-day Iran) in the third century CE. It grew from the ambition of one of the local rulers of the Parthian empire, the satrap of Pārs. This local ruler quickly overturned the central ruler of the Parthian empire, founded a new dynasty named after one of his ancestors (Sasan) and set out to conquer more territory.

The Sasanian period and empire lasted from 224 to $651 \mathrm{CE}$ when, due to a constantly weakening central government, increasingly independent local rulers and facing attacks from Heraclius, it gave way to the Arab conquest. For most of its history, the Sasanian empire was a strong military power and had important economic relations with the West, Egypt and India. On the crossroads of many trade networks, it benefited from the wealth and cultural exchange such networks provide. At its maximal extension, it ranged from the Caucasus in the North, Pakistan and Afghanistan in the East, the northern coast of the Arabian Peninsula and Mesopotamia in the South and West. Modern-day Iran and Iraq were the centre of the empire (see Fig. 1). Its capital, the seat of power, moved around the empire, but for much of the time, it was situated in Mesopotamia even though the ruling family originated from Pārs. 


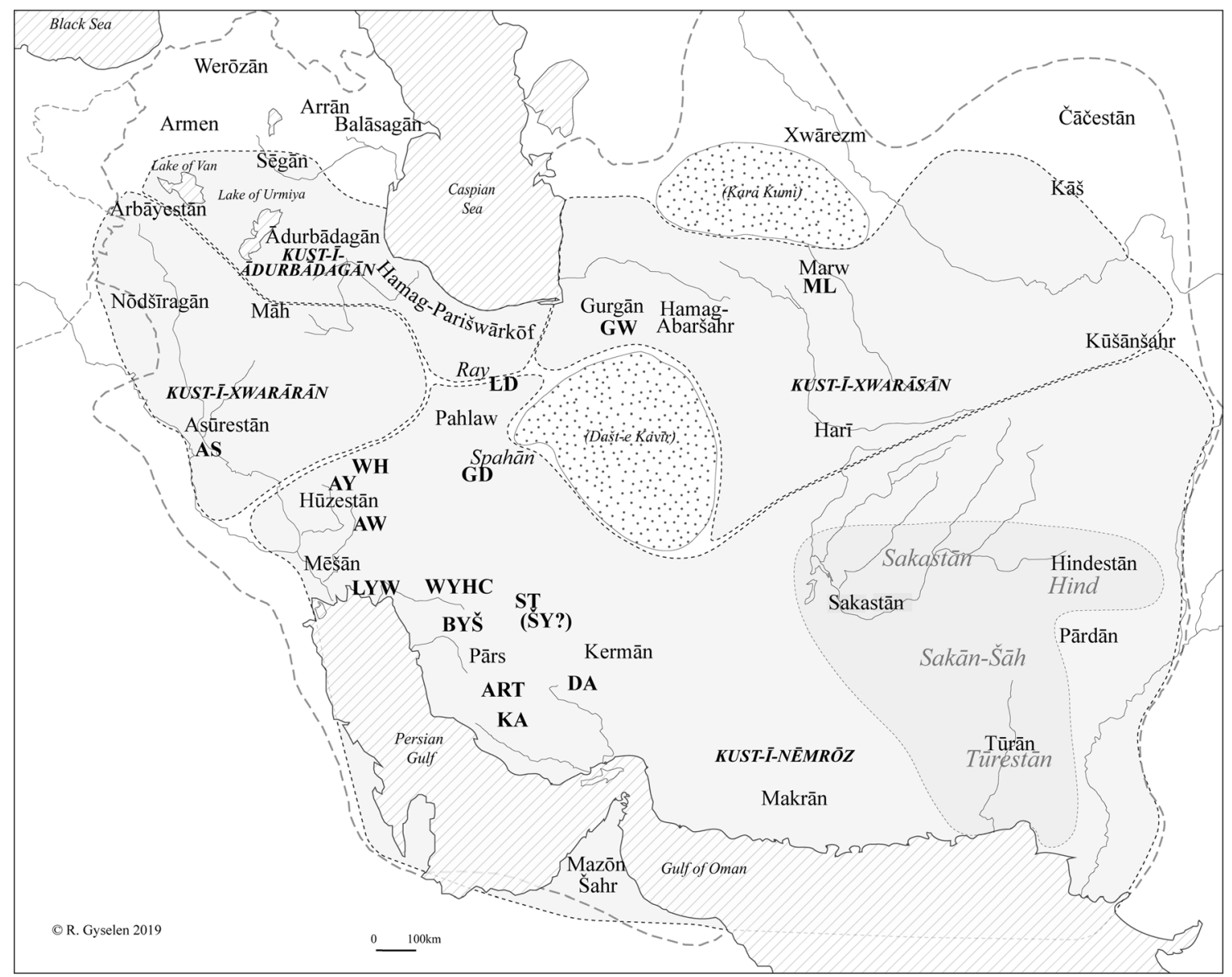

Fig. 1 Map of the Sasanian empire (limits at its largest are indicated by long dashed lines), regions and mints are indicated using different styles: lower case letters: regions mentioned in ŠKZ (inscription of Šābuhr I on the Ka'ba of Zoroaster, third century CE), italic lower case letters: regions of Ray and Spahān, according to KKZ (third century CE), larger italic

\section{Sasanian coinage}

Sasanian copper and billon coins exist in a variety of sizes and thicknesses and were produced in a large number of different mints. Silver coins are the "reference" coins for the Sasanian empire, usually called "drahm" (not to be confused with the "drachm" in ancient Greek context). These silver coins were mainly used for long-distance trade. This was not the case for coins in various alloys of copper and lead. Next in value are the tetradrahms made of silver-copper alloys (the lower silver content confers to them a lower value).

Information on the mint where a particular coin was struck can come in various forms. In the first century of the Sasanian era (i.e. third century CE), the name of the workshop is rarely given. The mint is then often determined according to stylistic criteria. In this work, mint attributions for that period are written between quotation marks ("attribution"). From the reign of Wahrām IV (388-399 CE) onwards, the indication of the mint becomes more common. During the reign of Pērōz (459-484 $\mathrm{CE}$ ), coins systematically bear the name of the mint. However, lower case letters (lighter shade): the kingdom of Sakān-šāh (the king of the Sakas) with Sakastān, Hind et Tūrestān. Upper case letters in italic and bold: the four kust (sixth century CE), limits indicated by short dashed lines and gray areas. Upper case bold letters: mint abbreviations found on coins (see also Table 1)

many mint names are limited to the first letters, which has given rise to confusion. The mints discussed in this work are found in Table 1 and the geographical distribution is illustrated in Fig. 1.

\section{Elemental analysis of Sasanian coins}

Recently, compositional analysis of Sasanian coins have been performed in the framework of the Sylloge Nummorum Sasanidarum (SNS) (Alram and Gyselen 2003; Alram and Gyselen 2012; Schindel 2004). Analysis of copper coins is limited to SNS I and II, i.e. kings Ardašīr I-Ohrmazd II (224 to $309 \mathrm{CE}$ ). As the Sasanian empire lasted until $651 \mathrm{CE}$, there is a large part of the record that still needs exploring (Šābuhr II to Yazdgerd III: 309 to $651 \mathrm{CE}$ ).

Within the publications of SNS, the analyses were performed using various methods such as XRF (Linke and Schreiner 2003), SEM-EDX (Linke and Schreiner 2003) and NAA (Barrandon 2003). Blet-Lemarquand (2012) presents a comprehensive overview of all the measurement methods 
Table 1 List of mints encountered in this work, abbreviations and likely locations are included. *Region: data provided by the inscription that Šābuhr I (241-272 CE) engraved on the Ka'ba of Zoroaster in Naqsh-i Rustam and by the inscription of Kirdīr (he was hērbed (a rank of Zoroastrian priesthood) under Šābuhr I and became High Priest under Wahrām II) on the same monument. **In the sixth century, the Sasanian empire was divided for military purposes into four zones: kust-1̄ xwarāsān "east side", kust-1̄ nēmrōz "south side", kust-1̄ xwarōfrān "west side" and kust- $\overline{1}$ Ādurbādagān "north side" (on this subject see Gyselen 2019, p. 127-139 and p. 269-277)

\begin{tabular}{llll}
\hline & Mint location & Region (3rd CE)* & Quarter (6th CE)** \\
\hline Mint & & & \\
"Sakastān" & "Sakastān" & Sakastān/Hindestān/Tūran & South \\
"A" & "Staxr" & Pārs & South \\
"B" & "Hamadān" & Māh & West \\
"C" & "Ctesiphon" & Asūrestān & West \\
Mint abbreviation & & & \\
ART & Ardašīr-xwarrah & Pārs & South \\
AS & Asūrestān & Asūrestān & West \\
AW & Ohrmazd-Ardašīr & Hūzestān & South \\
AY & Ẽān-xwarrah-Šābuhr (?) & Hūzestān & South \\
BYŠ & Bišābuhr & Pārs & South \\
DA & Dārābgerd & Pārs & South \\
GD & Gay & Pahlaw/Spahān & South \\
GW & Gurgān & Gurgān & East \\
KA & Kārzī & Pārs & South \\
LD & Ray & Pahlaw/Ray & South \\
LYW & Rēw-Ardasīr & Hūzestān & East \\
ML & Marw & Marw & East \\
ST & Staxr & Pārs & South \\
ŠY & Šīāz (?) & Pārs & South \\
WH & Weh-Andiyok-Šābuhr & Hūzestān & South \\
WYHC & Weh-az-Amid-Kawād & Pārs & South \\
\hline
\end{tabular}

used to analyse Sasanian coinage over time with their strengths and weaknesses.

The limited elemental analysis performed in the framework of the SNS changed our understanding of Sasanian coinage. One famous example are the coins of Ardašir I with two busts (Fig. 2C). They exist in two different monetary denominations: silver drahms and large copper coins. The latter monetary type seems to be limited to eastern Iran, corresponding to what was previously the Indo-Parthian kingdom. By analysing such a copper coin as well as two copper coins of Farn-Sasan, the last Indo-Parthian king, Barrandon (2003) suggested the existence, in this region, of a particular
Fig. 2 Illustration of Sasanian coins. (A) Coin no. 5.

Tetradrahm. Ardašìr I. Mint: "C". (B) Coin no. 23. Debased silver. Šābuhr I. Style Q. (C) Coin no. 17. Pure copper. Ardašîr I and Saka king. Mint: "Sakastān". (D) Coin no. 119. Copper. Kawād I. Mint: BYŠ (= Bišãbuhr). (After Gyselen and Mochiri 2017)

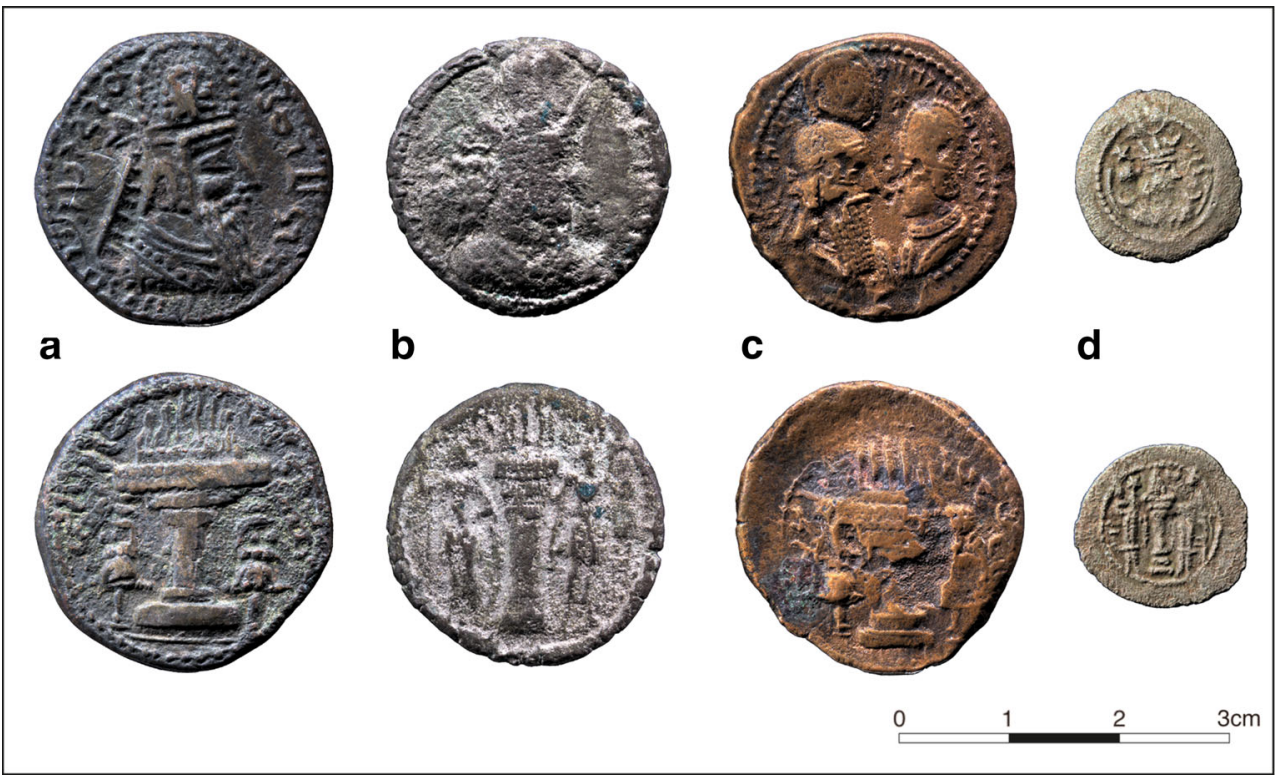


metallurgical tradition. Under the first Sasanian kings, who minted pure copper coins made up of $99.8 \mathrm{wt} \% \mathrm{Cu}$, this local tradition is perpetuated. Recently, a drahm with a legible obverse inscription: Ardašīir šāhān šăh Ardašīr Sakān šāh, i.e. "Ardašǐr king of kings (= Ardašīr I); Ardašīr king of the Sakas" (Schindel 2016) proved that these are indeed Sasanian emissions from eastern Iran. In that period, the Sasanian government had installed a viceroy of the Sakas in eastern Iran whose kingdom included, certainly from Šābuhr I onwards, Hind, Sakastān and Tūrestān all the way to the sea (= the Gulf of Oman). We choose to use the term Sakastān to indicate the Saka-kingdom (the darker shaded region on Fig. $1)$.

\section{Broader archaeological context}

Even if coins are a particular class of objects designed and used for trade, Sasanian copper coins cannot be seen outside the rich history of copper metallurgy in the region. Copper working on the Iranian plateau is attested from the seventh millennium BCE onwards (Oudbashi et al. 2012, 2017). There are many examples published in literature such as the remains of arsenical copper working in Bronze Age Tepe Hissar (where concomitant lead working is also attested) or the remains of copper working in Tel-e Mayan (Pigott 1980). On these sites, the main finds are slag remains and furnace linings (Pigott 1980). In other contexts, such as Mehrgarh in Pakistan, (traded) copper objects appear in aceramic (i.e. without ceramics) levels (Maddin et al. 1980). There is some evidence that, during the Early Bronze Age, relatively advanced copper metallurgy developed on the border between presentday Iran and Pakistan, which was organised in a domestic context rather than through large-scale specialised workshops (e.g. at Shahr-i-Sokhta: Hauptmann and Weisgerber 1980; Hauptmann et al. 2003). Specialised production of arsenical copper through speiss smelting is attested during the Early Bronze Age at Arisman (Rehren et al. 2012). Organised copper metallurgy, with specialised craftspeople, appears on the Iranian plateau as early as the fifth millennium BCE, long before it appears in Mesopotamia. This diachronic appearance is linked to the lack of copper deposits along the Tigris and the Euphrates (Berthoud et al. 1982), whereas many copper, lead and tin deposits are attested in Iran, particularly along the Sinandaj-Sirjan Zone (Momenzadeh 2004). By the 3rd millennium BCE, copper metallurgy was already well installed in the region and relied on Iranian copper deposits such as those found at Anarak (in the region of Isfahan). At the onset of the 2nd millennium BCE, the copper circulating in Susa (close to present-day Shush in Khuzestan, Iran) mainly originated from "Makkan" or "Magan", in present-day Oman (Berthoud et al. 1982; Begemann et al. 2010; Giardino 2019). There is, unfortunately, little or no information on copper export from Oman in later periods. It seems Oman was no longer a major copper source in the Hellenistic and Partho-Sasanian era when metals were obtained through mining activities within the Sasanian empire and through sea trade from the Mediterranean and the Indian subcontinent (Delrue 2008; Esposti et al. 2016).

\section{Research question}

This paper reports and discusses the composition of over 100 coins, which is an exceptionally large assemblage. This work contributes to the limited corpus of elemental analysis of copper alloy coins and broadens its timescale. It further provides a basis for the comparison of the coins from the Sasanian empire with the neighbouring regions and the other great empires before and after it. The large variability in production places and typology prompts the question whether these differences are reflected in the coins' elemental composition. This study allows an assessment of the distribution and use of raw materials in this huge empire. Furthermore, if specific compositions for particular mints can be identified, the composition of coins for which the mint is not indicated or cannot be read, may illuminate their production. Continuity and change over time are equally important as a proxy for the wider political and economic situation in the region.

\section{Materials and methods}

\section{Materials}

A total of 135 coins from the collections of the Royal Museum of Art and History, RMAH, spanning the reigns of Ardašir I (224-240 CE) to Yazdgerd III (632-651 CE) and from a large variety of mints (see Table 1) were analysed. These coins were previously described by Gyselen and Mochiri (2017), who interpreted the obverse and reverse, provided pictures of the coins, and reported on their weight and size. In the present assemblage 4 denominations of coins are found: drahms (whose normal composition is nearly pure silver), billon tetradrahms (a Ag-Cu coin), copper coins with a large flan and small copper coins. The catalogue of coins by Gyselen and Mochiri (2017) describes more coins than are reported here. The lead coins were already reported on in previous work (Van Ham-Meert et al. 2018). Some copper coins are not included in the present paper. This is linked to the lack of appropriate reference materials to accurately quantify the $\mathrm{Cu}$ $\mathrm{Pb}-\mathrm{Sn}$ concentrations in those alloys. Another problem encountered for some coins is a highly heterogeneous composition, with each measurement point yielding vastly different results from other points. For those coins, the best way to determine their average composition would be a destructive analysis of a homogenised sample. 


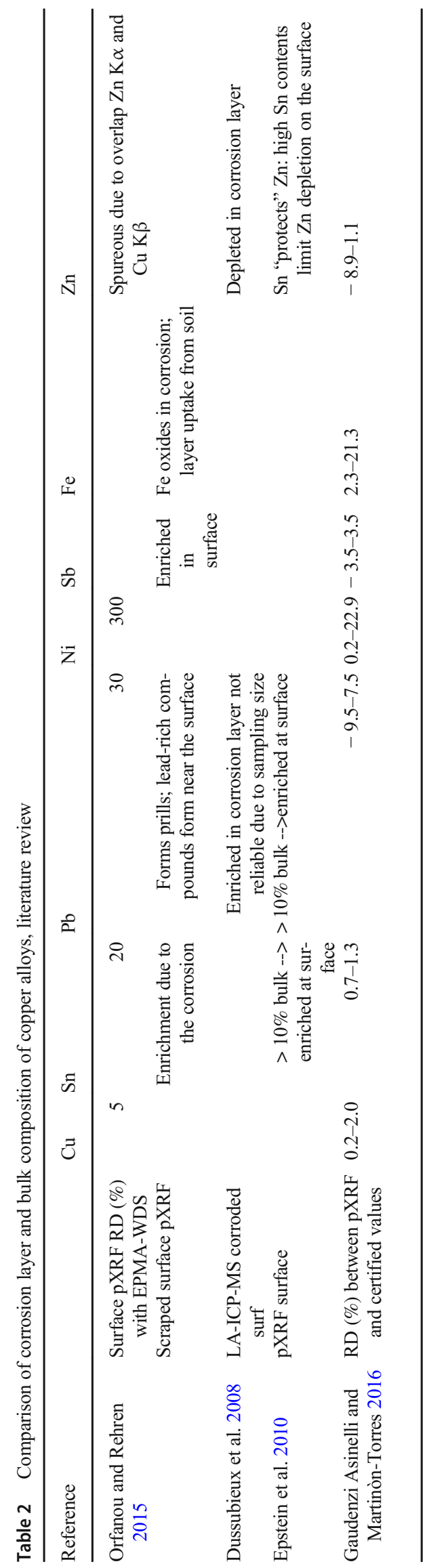

In this paper, coins from other publications will be referred to by their catalogue number in the original publication, whereas newly analysed coins will be referred to using both their code in the catalogue (Gyselen and Mochiri 2017) and their museum numbers as "catalogue/museum". This should ensure that any readers familiar with the catalogue or the museum records will be able to know which coins are discussed.

\section{Methods}

The coins were analysed at the Vrije Universiteit Brussel using an M4 Tornado micro-X-Ray fluorescence ( $\mu \mathrm{XRF}$ ) spectrometer from Bruker. No preliminary surface treatment of the coins was performed. The authors are not aware of any conservation treatments which the coins might have been subjected to; the coins were covered in a patina, typical for corroded coins, as illustrated in Fig. 2. Measurements were performed using the $\mathrm{W}$-tube at $50 \mathrm{kV}$ and $700 \mu \mathrm{A}$ in vacuum. Measurement spot size was $25 \mu \mathrm{m}$. Wherever possible, less corroded areas of the coins were selected for analysis (making use of the built-in microscope on the $\mu \mathrm{XRF}$ ). However, it has been shown that even on a sanded surface or a surface without visible corrosion, surface composition is not the same as in the bulk metal (e.g. for zinc: Dussubieux et al. 2008; Orfanou and Rehren 2015). A summary of expected discrepancies between surface and bulk analysis of copper alloys is provided in Table 2 and in the "Limitations of surface analysis, a literature review" section.

For one of the coins, both the obverse and reverse of the coins were measured. No difference was detected in the elemental composition: the difference between the obverse and reverse of the coin was in the same range as the difference between different measurement points on the same side of the coin. Therefore, and with the lack of available time in mind, only the obverse of the coins were measured henceforth. The coin for which this was done is not reported here, as it turned out to be a lead coin and included in the publication on that subject (Van Ham-Meert et al. 2018). Three replicate measurements of $120 \mathrm{~s}$ were performed for each coin, and the averages of those measurements are presented in the tables. Quantification was achieved using the fundamental parameter routine of the $\mu \mathrm{XRF}$ followed by an off-line calibration based on reference materials. First fundamental parameters is used to de-convolute and quantify each spectrum. The sum of elements linked to burial, corrosion or handling was always < $10 \mathrm{wt} \%$ and in most cases below $5 \mathrm{wt} \%$. The most prevalent of these was $\mathrm{Cl}$, followed by $\mathrm{Ca}$ and $\mathrm{K}$. Data was re-normalised to $100 \%$ without the contribution from these elements. This of course does not take into account the influence of this layer on the signal of other elements (due to the thickness of the layer, the intensity of the other elements is attenuated). Reference materials 31X 7835.5 A, 32X LB15, 31X B26 and 32X SN6, prepared for XRF analysis, were purchased from $\mathrm{MBH}$. The 
Fig. 3 Plot of values measured for reference materials (y-axis) and real values (x-axis). The reverse of the relationship between those is used to quantify the data
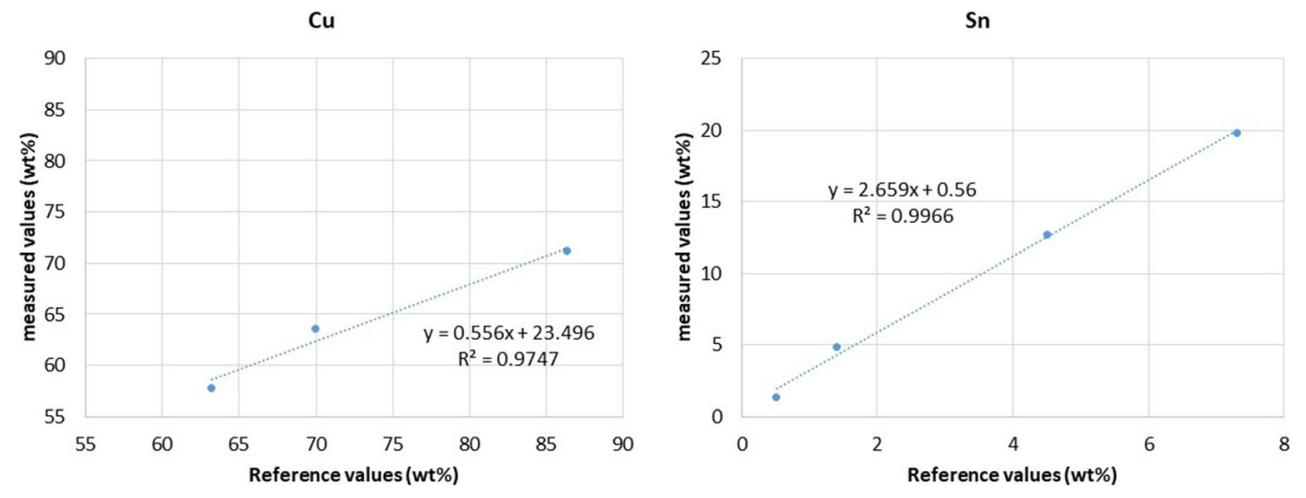

linear relationship between the certified values of the reference materials (x-axis) and the measured value was determined. $R^{2}$ values of 0.99 were found for most elements except copper $\left(R^{2}=0.97\right)$ (see Fig. 3). For lead, three reference materials have a concentration $<5 \mathrm{wt} \%$ and one close to $30 \%$, which leads to a bias in the calibration curve (which is determined using a least squares approach). However, since the aim is to obtain semi-quantitative data, this is sufficient. The inverse of these relationships is used to quantify the $\mu \mathrm{XRF}$ data.

Coins with less than $25 \mathrm{wt} \%$ copper cannot be quantified using this method. Any copper concentrations below $60 \mathrm{wt} \%$ are the result of extrapolation of the calibration curve to lower values and should therefore be treated with caution. The surfaces of reference materials appear uncorroded to the naked eye and were not prepared in any way (more details on potential problems with this approach are included in the "Limitations of surface analysis, a literature review" section). Quantification limits are included at the top of the tables for each element.

The composition of the reference materials, reported in Table 6 and ESI, is compared to the composition determined through the procedure described above. Surveying the results for the reference materials, a clear link between concentration and the obtained accuracy is observed. Higher concentrations lead to better accuracy (this is especially visible for Sn with a relative error of $42 \%$ at $0.5 \mathrm{wt} \%$ concentration and only $2 \%$ at $7.3 \mathrm{wt} \%$ ). In general, for concentrations above $0.5 \mathrm{wt} \%$, measurement errors are better than $10 \%$. Differences between quantified and certified concentrations for reference material 32X LB15 are much higher than for the other reference materials, presumably due to the presence of $21.5 \mathrm{wt} \%$ lead. In the other alloys, lead quantification is not satisfactory $(17-40 \%$ relative difference between quantified and certified values). It must be noted that these reference materials are copper-bronze alloys and no billon reference material was used. Notis et al. 2007 showed that for silver contents above $92 \mathrm{wt} \%$ (copper is soluble in silver up to $8 \mathrm{wt} \%$ ) pXRF analysis of silver coins is accurate. The elemental compositions of the archaeological coins are presented in Tables 3 (tetradrahms), 4 (drahms), 5 (copper coins with large flan) and 6 (small copper coins).

\section{Limitations of surface analysis, a literature review}

In order to correctly assess the obtained data, we surveyed the literature on bulk vs. surface analysis of copper alloys, focusing especially on XRF analysis of (corroded) surfaces: Dussubieux et al. 2008; Epstein et al. 2010; Figueiredo et al. 2007; Gaudenzi Asinelli and Martinón-Torres 2016; Orfanou and Rehren 2015; Shugar 2013.

Orfanou and Rehren (2015) measured both the corroded surface and the surface after scraping and compared it to EPMA data. The surface data is expressed as the relative difference to the EPMA data; for the scraped surface data, a qualitative appreciation was given. A summary of this review is presented in Table 2. Overall, XRF analysis of corroded surfaces tends to overestimate all elements (particularly lead and tin) except copper with respect to the bulk content. Particular corrosion effects may cause important depletion in elements such as zinc (dezincification), which is inhibited by the presence of tin. Conversely, tin is enriched on the surface when it is present in conjunction with zinc, whereas in high-tin bronzes it is usually depleted in the corrosion layer (Gaudenzi Asinelli and Martinón-Torres 2016). Crosera et al. (2019) found that $\mathrm{Cu}$ was slightly depleted on the surface $(91.7 \pm$ $3.1 \%$ determined by $\mu \mathrm{XRF}$ analysis) compared to the bulk $(95.9 \pm 3.1 \%$ determined by ICP-AES); however, taking into account their uncertainties, both results actually overlap.

It was also shown through replicate accelerated corrosion experiments of a $\mathrm{Cu}-\mathrm{Sn}(88: 12)$ alloy in different solutions (mimicking different environments) that those yield different corrosion layers (incorporation of $\mathrm{Cl}$ or $\mathrm{S}$ for example) and variable enrichment or depletion of certain elements (Robotti et al. 2018). This is also confirmed with archaeological examples of Roman coins from the Netherlands (Table 3 in Fernandes et al. 2013) or Islamic copper objects (Arafat et al. 2013). This considerably complicates the present 


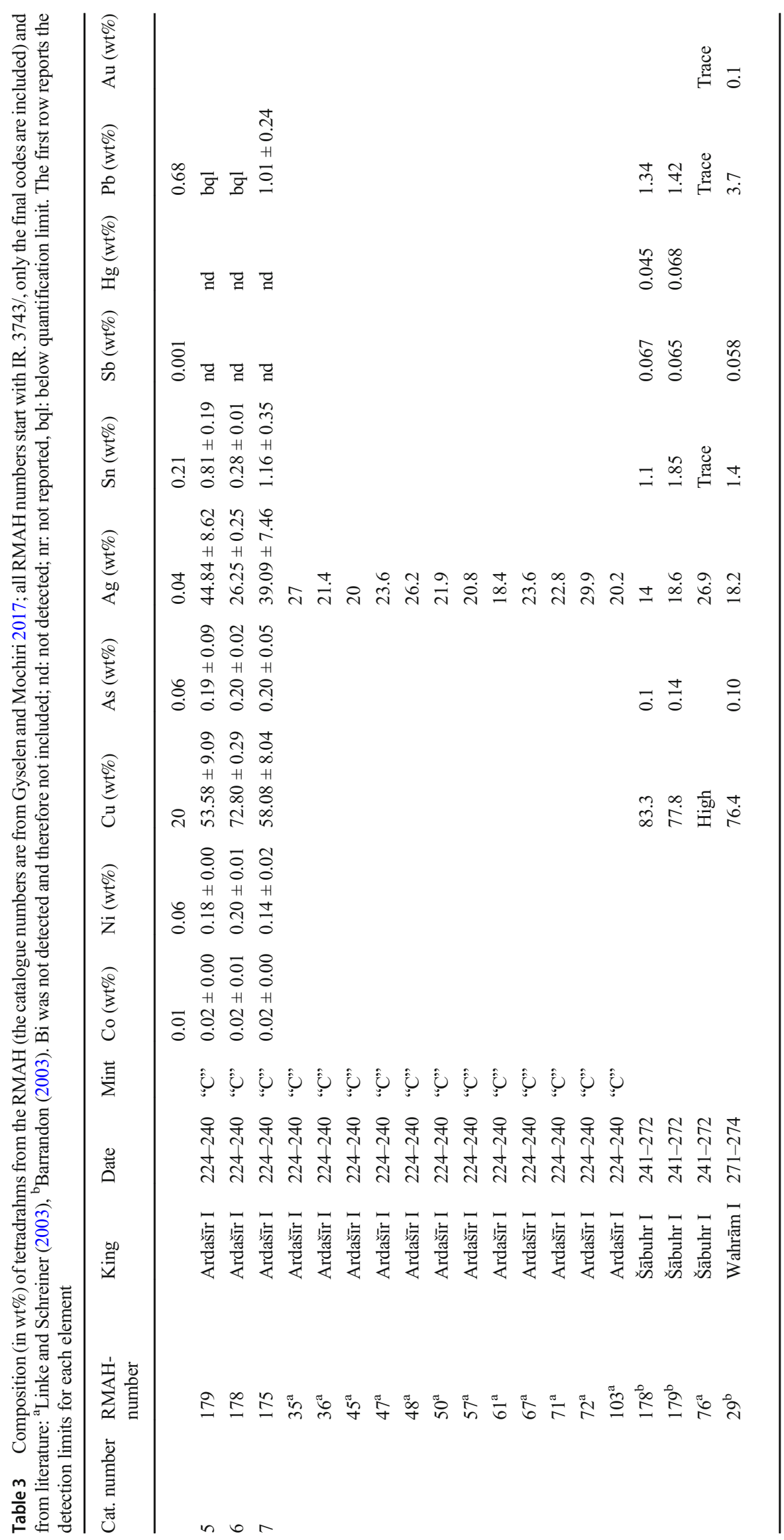


endeavour as we do not know where the coins where found and hence to what environment (temperature, $\mathrm{pH}$, redox...) they were subjected. Other factors influencing the formation of a corrosion/patina layer include the initial composition of the object, the microstructure and manufacturing process (Inberg et al. 2018). The colour of the corrosion can indicate what corrosion products were formed, e.g. red copper corrosion is likely cuprite, green corrosion is usually associated to $\mathrm{S}$ and $\mathrm{Cl}$ (Arafat et al. 2013). Inberg et al. (2018) even suggest that the nature of the corrosion layer can inform on the burial conditions. Di Turo et al. (2020) offer a visualisation of the formation of a corrosion layer and interface layer between the bulk coin and this corrosion layer based on measurements of all these layers and knowledge of the burial environment (latrinae).

One important difference between the literature reviewed and the present work is that most earlier papers focus on portable XRF. This method samples a relatively large area and is far less precise and accurate than benchtop ED-XRF. Furthermore, $\mu \mathrm{XRF}$ allows one to select the area more precisely. Nevertheless, the general observations on corrosion versus bulk are valid and are taken into account in the interpretation of the presented data. The small sample size in $\mu \mathrm{XRF}$ can lead to errors related to miscibility (e.g. copper and lead are immiscible: during analysis lead concentrations at grain boundaries may or may not be included) (Constantinides et al. 2001). Although this is partly compensated for by measuring multiple spots, this approach can lead to relatively large measurement uncertainties.

Few papers compare the bulk and surface composition of Ag-Cu alloys. One such study compared bulk (NAA) and surface (XRF) composition of $\mathrm{Ag}-\mathrm{Cu}$ coins from tenth to eleventh century Poland and found that for $16 \%$ of the coins within their assemblage the surface was enriched in Ag (8$22 \%$ difference between bulk and surface) (Bolewski et al. 2020). Linke and Schreiner (2003) proposed that the Ag L- $\alpha / \mathrm{Ag} \mathrm{K}-\alpha$ intensities could provide an indication of the thickness of the corrosion layer in $\mathrm{Ag}-\mathrm{Cu}$ alloys, by comparing the $\mathrm{Ag} \mathrm{L}-\alpha / \mathrm{Ag} \mathrm{K}-\alpha$ ratio in reference materials and in samples. L-lines are more attenuated than K-lines and therefore more representative of the surface, whereas K-lines provide information encompassing slightly deeper layers as well as the surface. Unfortunately, since we do not have such reference materials at our disposal, it was not possible to apply this method. Moreover, Bolewski et al. (2020) showed that this ratio was not always good at predicting surface enrichment of silver. Micro-XRF has a sampling depth which is higher than the corrosion layer of typically up to $50 \mu \mathrm{m}$ in Ag-Cu coins (Bolewski et al. 2020). The measured signal is thus a mixture of the corrosion layer and the deeper, sound metal, which usually leads to reasonable quantification (del Hoyo-Meléndez et al. 2015). Gore and Davis (2016) performed a series of analysis of $\mathrm{Greek} \mathrm{Ag}-\mathrm{Cu}$ coins to evaluate different measurement instruments and settings. In one experiment, they compared ED-XRF analysis of untreated coins with measurements of abraded surfaces (i.e. without the patina). They concluded that $\mathrm{Si}, \mathrm{S}, \mathrm{Fe}, \mathrm{Cl}$ and $\mathrm{Br}$ were enriched in the patina, $\mathrm{Cu}$ and $\mathrm{Pb}$ were depleted in the patina and $\mathrm{Ag}$ (and potentially $\mathrm{Au}$ ) have the same concentration in both the patina and the bulk. For a number of elements (e.g. Ti, V, Cr, Ca), there is no straightforward conclusion as they sometimes are enriched in the patina and sometimes not. They also show that removing elements associated to the burial environment ( $\mathrm{Si}$, $\mathrm{Cl}, \mathrm{Ca}, \mathrm{Na}, \ldots$ ) and re-normalizing the data from the measurements of the patina yield results close to those obtained for the abraded surfaces (Gore and Davis 2016). As for the corrosion observed on copper alloy coins, corrosion products and patina composition differs between different coins (Keturakis et al. 2016). This difference was attributed to different burial environment, different treatment once it left the ground, slightly different alloy composition, ...

In general, it must also be kept in mind that copper alloys have complex microstructures which might lead to large compositional variations on a small scale (due to the immiscibility of different metals and the presence of different phases within the object) (Constantinides et al. 2001). Furthermore, $\mu \mathrm{XRF}$ by its very nature is a surface analysis, and it is most likely that the analysis did not reach the uncorroded core of the coin. Nevertheless, this surface analysis can still be informative if those limitations are kept in mind.

\section{Results}

\section{Setting the scene}

In order to facilitate the discussion of coin compositions, a few conventions are made based on metallurgical considerations. Some coins consist of binary $\mathrm{Cu}-\mathrm{Ag}$ alloys, but most are ternary or quaternary alloys (Cu-(Ag)-(Sn)-Pb). For ease of comprehension, two types of binary alloys are described $\mathrm{Cu}-\mathrm{Ag}$ and $\mathrm{Cu}-\mathrm{Sn}$. Copper coins with up to $5 \mathrm{wt} \% \mathrm{Ag}$ are defined as copper coins with silver. In the Roman period, it is not uncommon to have copper coins with a few weight percent silver, the proportion of silver determining the value. Bollard and Barrandon (2006) report copper nummi with 2-7 wt\% silver, $5 \mathrm{wt} \%$ lead and $<3 \mathrm{wt} \%$ tin (it must be noted that in their analysis of Roman, Byzantine and Umayyad coins from Jordan, Birch et al. (2019) did not detect silver). Coins with $10-75 \mathrm{wt} \%$ silver and the rest copper are called billon and coins with 75-95 wt\% silver are called debased silver. In silver coins, copper can be added for up to $5 \mathrm{wt} \%$ to increase the hardness (Masjedi et al. 2013). One other important feature of the $\mathrm{Cu}-\mathrm{Ag}$ phase diagram is the presence of a eutectic with $71.9 \mathrm{wt} \%$ silver and $28.1 \mathrm{wt} \%$ copper; a melt of that composition yields the lowest solidus point at $780{ }^{\circ} \mathrm{C}$ (Oudbashi et al. 2017). The 

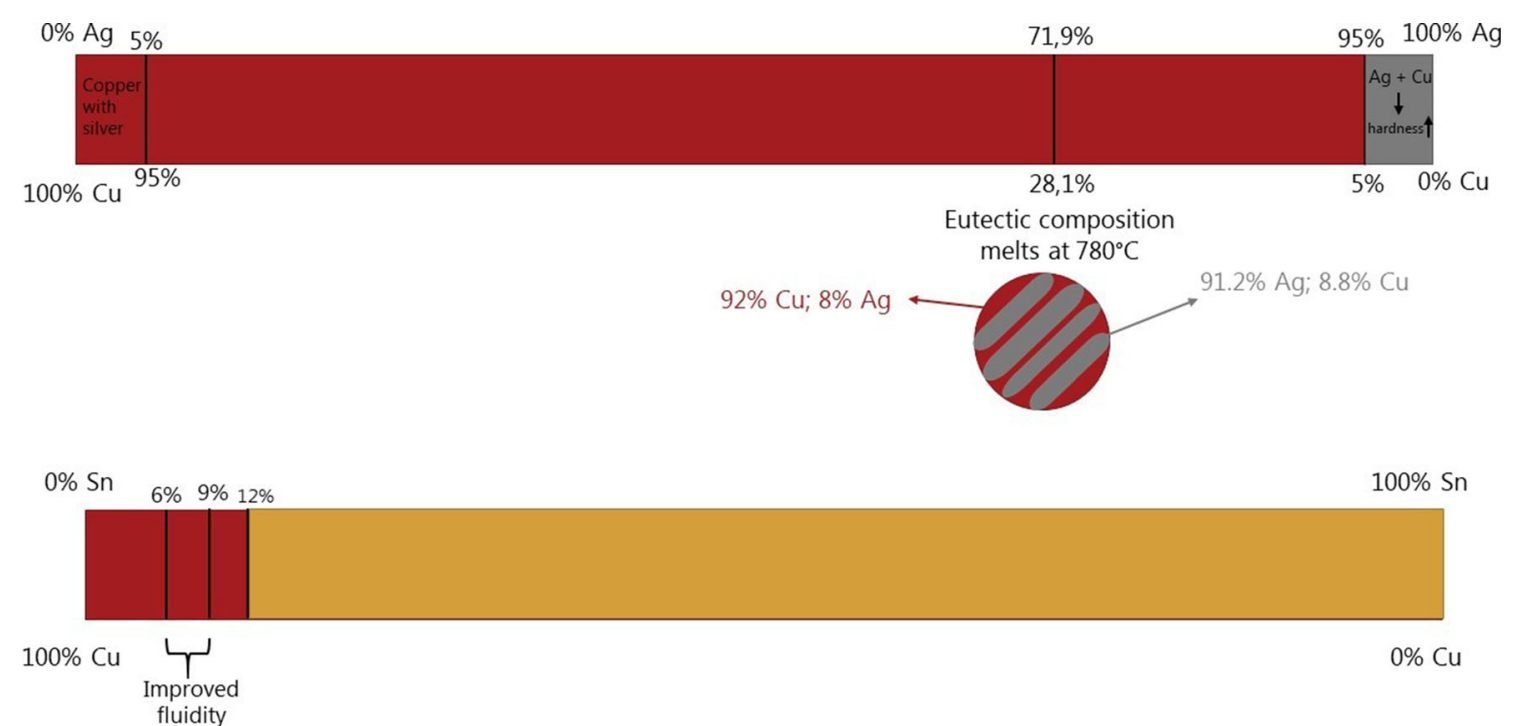

Fig. 4 Top: Ag-Cu alloys, with an illustration of the microstructure and composition of each phase in a eutectic alloy, copper with up to $5 \mathrm{wt} \%$ is called copper with silver. Silver with up to $5 \mathrm{wt} \%$ copper is silver with copper, where copper is added to increase the hardness of the alloy.

microstructure of a eutectic solid is also included in Fig. 4. Tin is added to copper for a variety of reasons. Most commonly, it is present in low concentrations (6-9 wt\%) to improve fluidity, while at concentrations above $12 \mathrm{wt} \%$, the alloy colour changes to a more golden-yellow tint.

\section{General observations}

There seems to be a "background" signature of zinc in all of the coins: there is a small peak visible at the $\mathrm{Zn} \mathrm{K} \alpha$-line, i.e. it is not the off-line calculations which leads to "numbers". Therefore, either zinc is present in all the coins or the zinc signal is a consequence of the spectral overlap of $\mathrm{Cu} K \beta$ lines with $\mathrm{Zn} \mathrm{K} \alpha$ lines (Orfanou and Rehren 2015). This second explanation seems more likely in this case, though the presence of zinc can, of course, not be ruled out. Given the uncertainty, zinc is not included in the tables.

In some coins, elevated calcium, iron and silicium levels were measured as a consequence of residual soil on the objects. The presence of iron in the bulk of a(n) (arsenical) copper coin can have multiple, not mutually exclusive, origins. Primary (raw) copper can incorporate up to several percent of iron in the metallic state when sufficiently reducing conditions dominate the smelting process and the furnace charge (the ore, flux or technical ceramics) contains iron (Craddock and Meeks 1987). Iron may be incorporated as part of slag inclusions. This happens for both oxidic (e.g. Tylecote et al. 1977) or sulphidic (e.g. Rehren et al. 2012; Masjedi et al. 2013; Oudbashi et al. 2017) ore smelting, including the smelting of arsenopyrites. Much of this iron can be removed during a secondary melting operation (refining), although some iron invariably remains in the metal. However, when performing
Bottom: Cu-Sn alloys, between 6 and 9 wt $\%$ of $\mathrm{Sn}$ in copper improve the fluidity of the alloy, ideal for casting. Above $12 \mathrm{wt} \%$ of Sn the alloy colour becomes more golden used to mimick gold in certain objects

surface analysis, most of the iron usually is related to incomplete removal of soil residues (Hajivaliei and Khademi Nadooshan 2012; Notis et al. 2007) and iron content is therefore not discussed in this work.

\section{Coins with > 5 wt $\%$ silver}

Under this heading fall two denominations: drahms and tetradrahms. Throughout this paper, as per numismatic convention, drahms and tetradrahms are abbreviated to $\Delta$ and $4 \Delta$ respectively. The weight of the coins provides a means of differentiating them: $\Delta$ coins weight between 2.84 and $5.08 \mathrm{~g}$ and $4 \Delta$ coins between 9.87 and $13.18 \mathrm{~g}$.

\section{Tetradrahms $(4 \Delta)$}

Tetradrahms from this work, as well as from earlier publications, are reported in Table 3 (Barrandon 2003; Linke and Schreiner 2003). Among the $4 \Delta$ appearing in the catalogue (Gyselen and Mochiri 2017): 4/181, 5/179, 6/178 and 7/175 coins, 5/179, 6/178 and 7/175 are indeed made of a $\mathrm{Ag}-\mathrm{Cu}$ billon alloy with silver concentrations between 26 and 45 $\mathrm{wt} \%$. So far, most analysed coins contain $18-30 \mathrm{wt} \%$ silver (Barrandon 2003; Linke and Schreiner 2003). This is a large variation in concentrations which indicates the value of the coins (i.e. silver content) was not as tightly controlled as one might expect. The difference in silver content can in part be attributed to surface enrichment. The main other element present is copper whose partial surface depletion (leading to variable contents) can be linked to copper corrosion. Coin 5/179 further contains just below $1 \mathrm{wt} \%$ tin, while coin $7 / 175$ contains approximately $1 \mathrm{wt} \%$ tin and lead each. Trace element 
compositions are similar for the three coins. Coin $4 / 181$ is not made of a silver-copper alloy but of leaded tin-bronze and is discussed with the copper coins of large flan (Table 5).

\section{Drahms $(\Delta)$}

This group of coins appears in the catalogue (Gyselen and Mochiri 2017) under different denominations: either as billon coins $(23 / 182,26 / 186)$ or as copper coins (AE) $(24 / 185,25 /$ $187,27 / 184,28 / 12)$. These denominations, empirically determined, could sometimes be corrected thanks to these compositional analyses (based on the analysis, Gyselen re-assessed those coins).

Coins 23/182 and 26/186 contain more than $85 \mathrm{wt} \% \mathrm{Ag}$ debased using a leaded bronze in the case of $23 / 182$, and with pewter (tin and lead) for 26/186. Coin 28/12 consists of silver alloyed with $30 \mathrm{wt} \%$ tin, $14.4 \mathrm{wt} \%$ lead and $1.9 \mathrm{wt} \%$ arsenic. This might in fact also be the composition of coins 120, 139, 142 reported by Linke and Schreiner (2003). They are characterised by $62.3,49.5$ and $61.6 \mathrm{wt} \%$ silver respectively and further have an undefined "high" tin and lead content (Linke and Schreiner 2003; Barrandon 2003). Whether or not they contain any copper is not reported and what is remarkable about coin $28 / 12$ is the absence of copper in the alloy.

Most of the other coins in literature and in this assemblage contain between 5 and $20 \mathrm{wt} \%$ silver, which is similar to the silver contents found in billon coins outside the Sasanian empire such as the coins from Valerianus (Linke and Schreiner 2003). It also is close to the compositions reported for "bronze à argent" Roman nummi (Bollard and Barandon 2006). Those nummi as well as coins 25/187,133,130,132 and 136 contain lead and tin. The absence of a definition of the value "high" by Barrandon (2003) prevents further discussion on this subject. Coins 27/184 and 24/185 on the other hand contain a little tin, but no lead. The only exceptions are two coins with close to $30 \mathrm{wt} \%$ silver: 165 and 141 reported by Linke and Schreiner (2003).

\section{Copper coins}

Two denominations are dealt with in this section: copper coins with large flan ${ }^{1}$ ranging in diameter from 22 to $30 \mathrm{~mm}$ and "small" copper coins.

\section{Copper coins with large flan}

Compositional analysis of copper coins with large flan are found in Table 5. All the coins produced in Sakastān (except a coin of Ohrmazd II: no. 50 reported by Blet-Lemarquand 2012) are made from pure copper and date to the early Sasanian period. Those struck under the reign of Ardašìr I

\footnotetext{
${ }^{1}$ The flan is the (blank) disk, which is then struck to produce a coin.
}

(such as 17/180 and 18/177) present an exceptional obverse iconography with two busts: on the left that of Ardašĩr king of kings and on the right a smaller bust, that of Ardašīr king of the Sakas.

Coins 4/181 and 16/176 are not pure copper coins; instead, they are leaded bronze coins similar in composition to some of the small copper coins labelled HPbHSn. Coin 60 (BletLemarquand 2012) contains no tin but only copper and lead, similar to the small copper coins labelled $\mathrm{HPb}$. This points towards the use of the same alloy to produce both large and small copper coins.

This further indicates that the mints in the Sakastān region were producing far purer coins than in other regions.

\section{Small copper coins}

Apart from the nearly pure copper coins with large flan produced in Sakastān, a number of almost (98-100 wt\%) pure copper coins were struck in various mints in Pārs (DA, ST, ART and BYŠ) and one coin is attributed to mint AW in Khuzistan. A negative correlation between the copper and arsenic content is observed in these coins (see Fig. 5). Most of these coins are from the reigns of Kawād I and Husraw I, so they are confined to a particular period. Table 6 reports the $\mathrm{Cu}$, $\mathrm{As}, \mathrm{Sn}$ and $\mathrm{Pb}$ composition of the small copper coins (the complete composition is found in ESI), those with a negative correlation between arsenic and copper are labelled with ACL.

From Figs. 6 and 7, it is clear that the other copper coins contain variable concentrations of both tin and lead without any link to either mint or reign. Some early coins from the reigns of Ardašir I, Šābuhr I and II are characterized by 14 to $43 \mathrm{wt} \%$ lead (considered "high" despite possible overestimation due to surface effects, cfr. "Limitations of surface analysis, a literature review" section). These coins are also characterized by tin contents between 7 and $14.5 \mathrm{wt} \%$ (labelled HPbHSn in Table 6). One of these coins, coin $52 / 26$, is similar to coins reported by Göbl (1984, p. 134) and Schindel (2004, vol. 3/2, p. 36 and pl. 4, nos. 48, 49, A10), which are overstruck on Roman copper coins. For coin 52/26, the trace of the previous striking is still visible but could not be identified.

During the reigns of Yazdgerd II, Pērōz and Kawād I, elevated lead contents are found for one or two coins without elevated tin (labelled $\mathrm{HPb}$ in Table 6). Coins produced at both $\mathrm{WH}$ and $\mathrm{AY}$ fall in this category, though in general coins produced at $\mathrm{AY}$ are associated with low tin contents $(<1.5 \mathrm{wt} \%)$.

A large group of coins contains 0.5 to $2 \mathrm{wt} \%$ tin mainly during the reigns of Wahrām V and Yazdgerd II.

\section{Discussion}

During the reign of Ardašîr I, pure copper, billon and leaded bronze coins ( $\mathrm{HPbSn}$ ) are found. Under the rule of Šābuhr I, a 
Fig. 5 As vs $\mathrm{Cu}$ content for Sasanian copper coins grouped by mint/region of production. In the top left corner, the range 98-100 wt $\% \mathrm{Cu}$ is enlarged to see the negative linear correlation between arsenic and copper. Errors are not plotted, but reported in Table 6, they are around $5 \mathrm{wt} \%$ for $\mathrm{Cu}$ for concentrations above $80 \mathrm{wt} \%$ and around $0.05 \mathrm{wt} \%$ for As

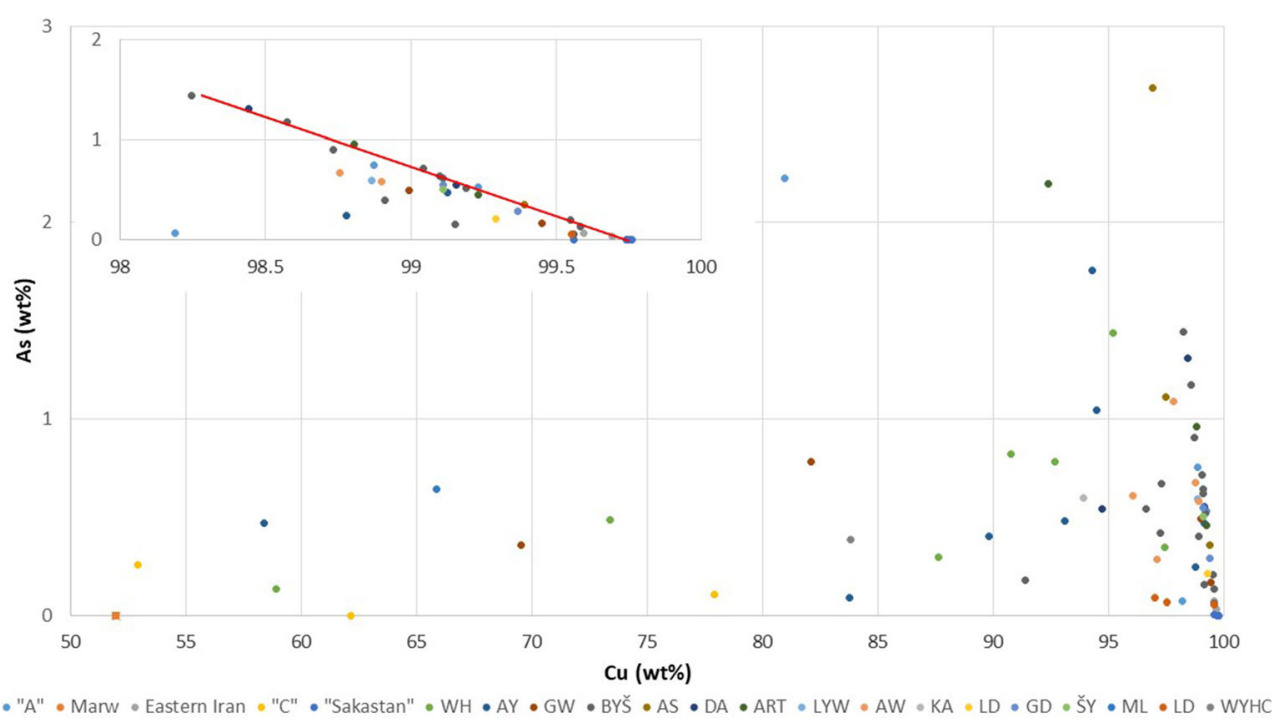

new type of alloy completes this set: leaded copper ( $\mathrm{HPb})$. The presence of leaded copper can be understood as a form of debased copper coins, but it should also be noted that they are produced in a different location. Both pure copper and leaded copper coins persist in the record until the end of the Sasanian empire.

\section{Pure copper coins with a large flan}

The earliest pure copper coins with large flan are from Sakastān, the only exception is coin 50 from the reign of Ohrmazd II (302-309) reported by Blet-Lemarquand (2012), discussed below. The tradition of pure copper coins predates the Sasanian period. Indo-Parthian coins, such as those from Farn-Sasan, were already made of pure copper (Table 4; Schindel 2015 and Shavarebi 2017). Large copper coins from Šābuhr II (40/192, 41/191, 44/193 and 45/189) were tentatively attributed to Sakastān by Gyselen and Mochiri (2017) awaiting confirmation from elemental analysis. The present results show that those coins are indeed pure copper coins with all trace elements below detection limits, like the Ardašīr I coins from Sakastān, providing a strong argument in favour of this attribution.

Large copper coins produced in Sakastān start circulating in the empire after its annexation by Ardašìr I and are clearly a consequence of mints used by the Indo-Parthian rulers now being used by the Sasanian authorities. The use of pure copper might be incidental rather than purposeful, simply as a consequence of the use of copper from mines with pure copper ore (Shavarebi 2017). Shavarebi (2017) notes that under Ohrmazd II (302-309 CE), there are two types of copper coins produced in Sakastān. One type is the classical pure copper type (Alram 2007, Table 1) and the second one with lead (6.6 wt\%) and tin $(1.8 \mathrm{wt} \%)$. He bases this second type on the sole report of one
Fig. $6 \mathrm{~Pb}$ vs $\mathrm{Cu}(\mathrm{wt} \%)$ content of the coins grouped by king and by mint/region of production. In the blue box, a group of highly leaded copper coins. The billon coins are excluded from this graph. The left graph displays the coins by king, the right one by mint, since all mints are not known there are fewer coins on the right graph. Errors are not plotted, but reported in Table 6, they are around $5 \mathrm{wt} \%$ for $\mathrm{Cu}$ for concentrations above $80 \mathrm{wt} \%$ and range $8-15$ $\mathrm{wt} \%$ for $\mathrm{Pb}$
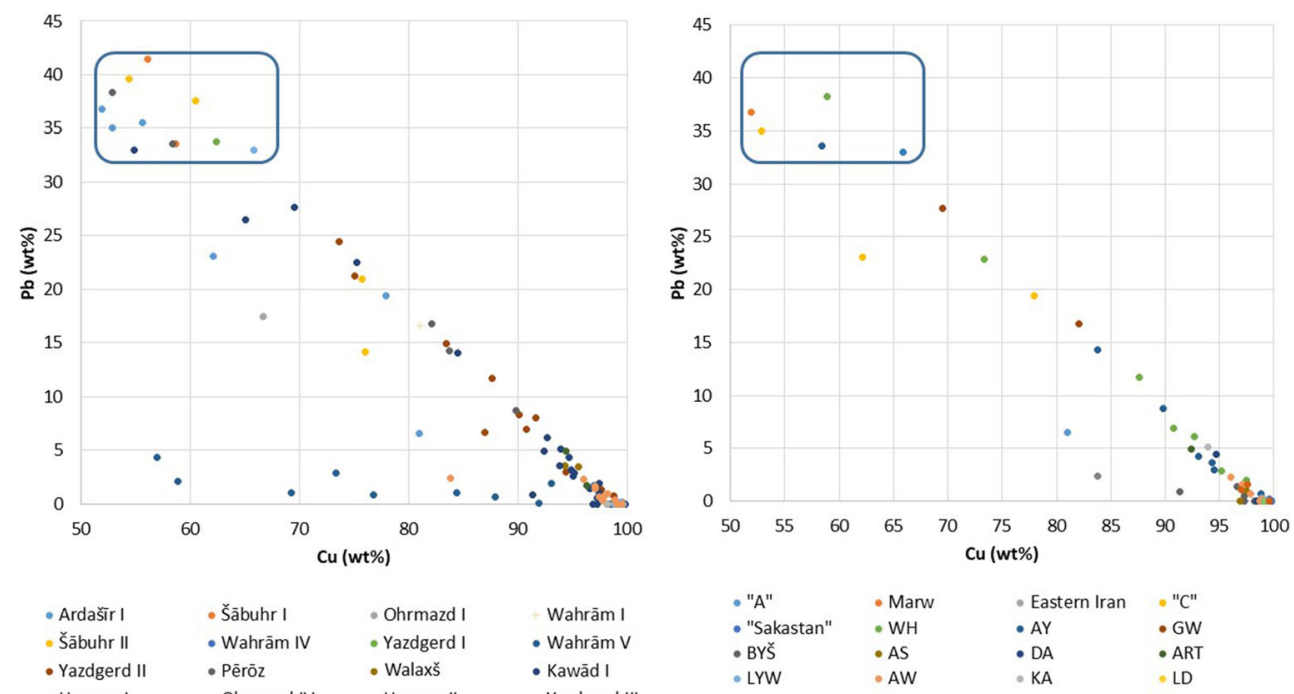
Fig. $7 \mathrm{Sn}$ vs $\mathrm{Cu}$ content of the coins grouped by king (left) and by mint (right), excluding billon coins. Errors are not plotted, but reported in Table 6, they are around $5 \mathrm{wt} \%$ for $\mathrm{Cu}$ for concentrations above $80 \mathrm{wt} \%$ and about $5 \mathrm{wt} \%$ for $\mathrm{Sn}$
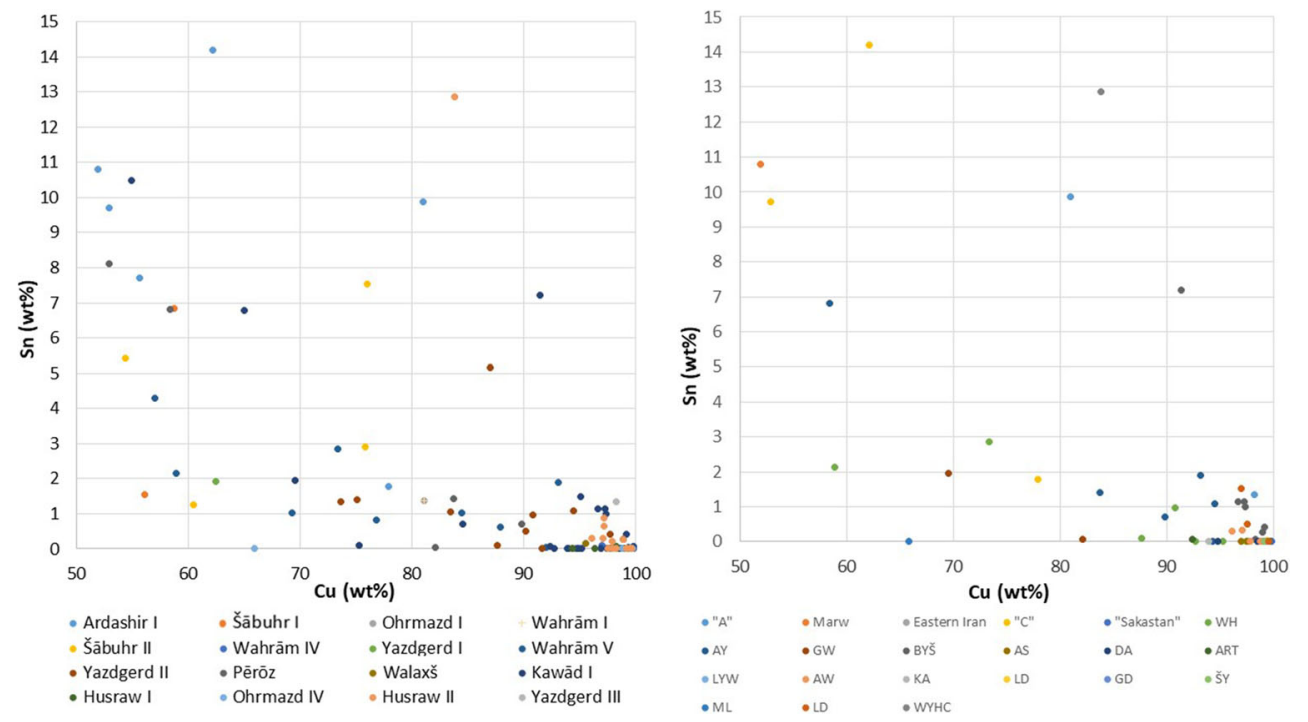

coin by Blet-Lemarquand (2012). Blet-Lemarquand interpreted this coin as a possible change in composition for coins from Sakastān, incorporating both higher lead (as opposed to maximally $2 \mathrm{wt} \%$ before, according to her) and tin levels. Shavarebi (2017) further attributes this change in composition to the exploitation of new mines containing lead and tin. In Sakastān, a number of mines are known to have been in use since antiquity: Qal'eh Zari and Qolleha in the West and Chel Kureh, Siah Gekul and Hagi Koshteh in the North (Shavarebi 2017). Qal'eh Zari not only contains copper but also gold, lead, zinc and silver, whereas Chehel Kureh also produces zinc and lead. However, none of these yield tin, so incidental production of bronze seems unlikely. Sakastān does have some tin mines such as Zarang (close to the Hamun-lake) so it is possible bronze coins were purposely alloyed and copper coins which were not alloyed were kept pure on purpose as well.

In this paper, all the coins from Sakastān produced under Šābuhr II (309-379 CE), who succeeds to Ohrmazd II, are made of pure copper. This goes against the previous suggestion that a new or second recipe was present in Sakastān from Ohrmazd II (302-309 CE) onwards (Shavarebi 2017).

\section{Small copper coins}

The small pure copper coins produced in Pārs almost invariably contain arsenic. Arsenic is volatile and may be lost to some extent during repeated metallurgical operations, particularly under (partly) oxidising conditions (Mödlinger et al. $2018,2019)$. The distribution of arsenic in these coins is plotted in the histogram in Fig. 8. The distribution is characterised by a maximum around $0.5 \mathrm{wt} \%$ As and a tailed normal distribution around this value. This indicates the use of raw copper naturally containing a low arsenic concentration; ore deposits from which such copper could be smelted exist, e.g. in the
Anarak region in central Iran (Bagheri et al. 2007). Alternatively, perhaps less likely, this can be attributed to (re-)use of copper actively alloyed with arsenic. The use and production of arsenical copper is well documented on the Iranian plateau, where it remains one of the most common alloys until the Iron Age (Thornton et al. 2002). In some publications on arsenical coppers and/or coppers with traces of arsenic, the purposeful alloying and the smelting of arsenic containing copper ore are mentioned as possibilities (Oudbashi et al. 2020; Oudbashi et al. 2017), while Rehren et al. (2012) argue for the preparation of speiss (probably from arsenopyrite) for the production of arsenical copper in Bronze age Arisman.

Under Pērōz, there is one pure copper coin in the present assemblage (106/90) which does not bear a mint mark. We suggest it is not from Pārs as the coins produced in Pārs during this period contain arsenic and this coin does not. It must be noted though that there are only 6 coins from the reign of Pērōz, one of which is a pure copper coin. More pure copper coins from that period might illuminate this matter.

Arab-Sasanian copper ( $>98 \mathrm{wt} \%$ copper) coins produced after the fall of the Sasanian empire with typologies similar to the Sasanian typologies are also reported (more details in BletLemarquand et al. 2014), which again shows that this recipe persists beyond the end of the Sasanian period.

Coin 102/88 bears the mark of a mint which was illegible. Gyselen and Mochiri (2017) thought it might be WH, but since coin 102/88 contains more lead than both WH coins from the reign of Yazdgerd II and is associated to $1 \mathrm{wt} \%$ tin, an attribution to AY would be more likely, from an analytical point of view.

During the reigns of Yazdgerd II to Husraw II, the assemblage contains nearly pure copper coins with 1 or $2 \mathrm{wt} \%$ lead and traces of silver, where the silver and lead are positively correlated (labelled $\mathrm{AgPb}$ in Table 6). This could be due to the 


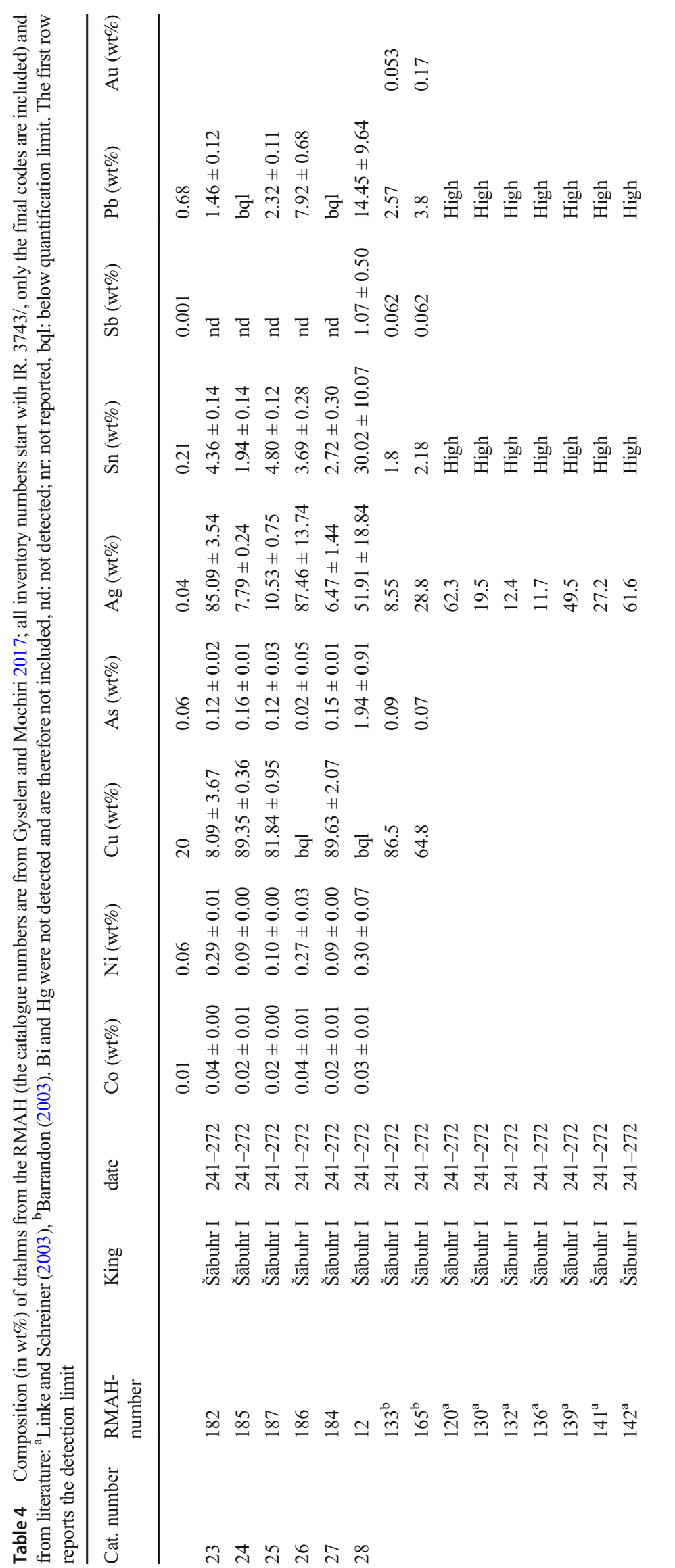




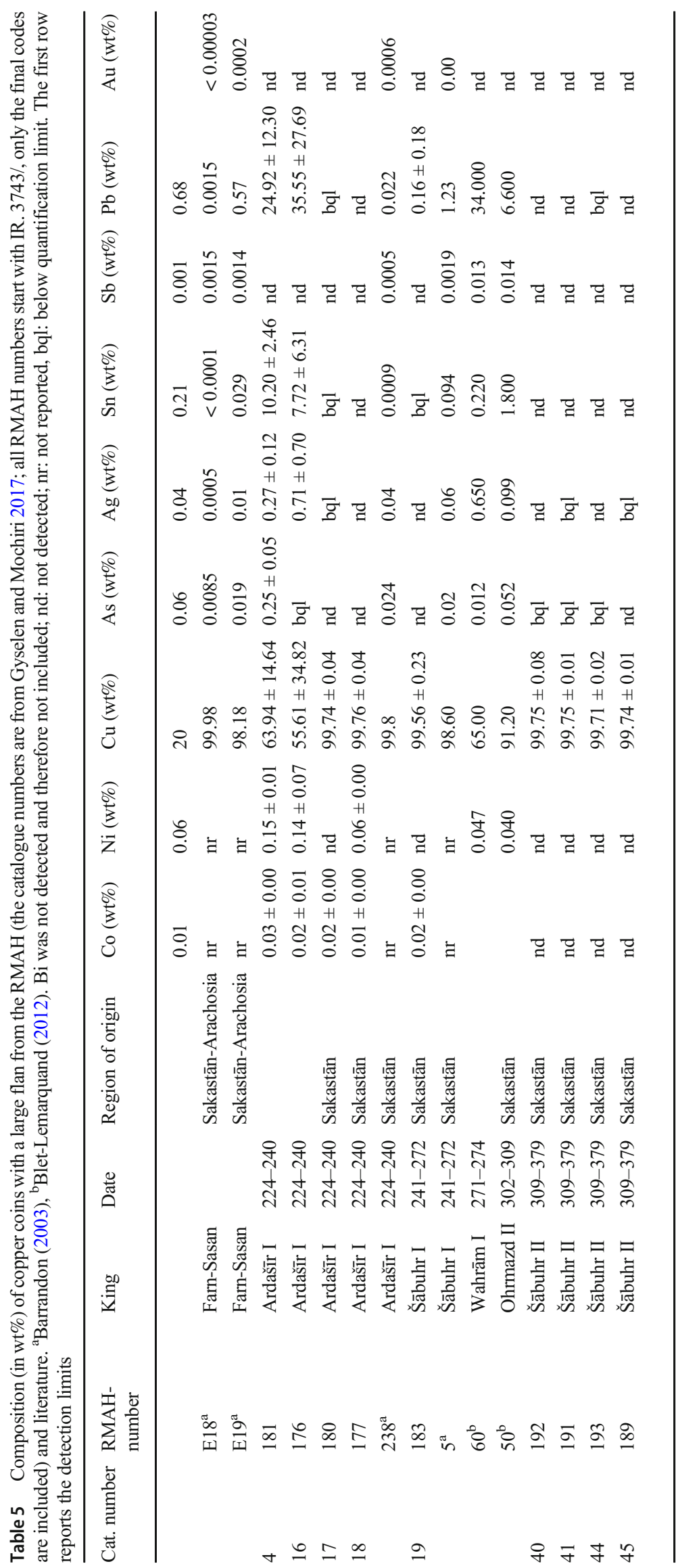


Table $6 \mathrm{Cu}$, As, $\mathrm{Sn}$ and $\mathrm{Pb}$ content (in wt\%) of small copper coins from the RMAH (the catalogue numbers are from Gyselen and Mochiri 2017; all RMAH numbers start with IR. 3743/, only the final codes are included) and literature. ${ }^{\mathrm{a} B a r r a n d o n}$ (2003), ${ }^{\mathrm{b}}$ Blet-Lemarquand (2012). Detection limits are reported in the first row, values for references materials are included at the bottom

\begin{tabular}{|c|c|c|c|c|c|c|c|c|c|}
\hline Cat. number & $\begin{array}{l}\text { RMAH- } \\
\text { number }\end{array}$ & King & Date & Mint/origin & $\begin{array}{l}\text { Chemical } \\
\text { group }\end{array}$ & $\mathrm{Cu}(\mathrm{wt} \%)$ & As (wt\%) & $\mathrm{Sn}(\mathrm{wt} \%)$ & $\mathrm{Pb}(\mathrm{wt} \%)$ \\
\hline & & & & & & 20 & 0.06 & 0.21 & 0.68 \\
\hline 3 & 3 & Ardašīr I & $224-240$ & "A" & & $80.95 \pm 6.62$ & $2.22 \pm 0.41$ & $9.88 \pm 0.26$ & $6.54 \pm 6.11$ \\
\hline \multirow[t]{2}{*}{12} & 7 & Ardašīr I & $224-240$ & "Marw" & $\mathrm{HPbHSn}$ & $51.92 \pm 18.40$ & nd & $10.81 \pm 0.56$ & $36.79 \pm 15.26$ \\
\hline & 8 & Ardašīir I & $224-240$ & "C" & $\mathrm{HPbHSn}$ & $62.15 \pm 9.07$ & nd & $14.20 \pm 0.55$ & $23.10 \pm 8.44$ \\
\hline 14 & 11 & Ardašīr I & $224-240$ & "C" & HPbHSn & $52.89 \pm 0.83$ & $0.26 \pm 0.05$ & $9.71 \pm 0.40$ & $35.03 \pm 1.07$ \\
\hline 15 & 10 & Ardašīr I & $224-240$ & "C" & $\mathrm{HPb}$ & $77.91 \pm 6.51$ & $0.10 \pm 0.08$ & $1.77 \pm 0.81$ & $19.38 \pm 5.67$ \\
\hline 20 & 16 & Šābuhr I & $241-272$ & & $\mathrm{HPbHSn}$ & $38.24 \pm 17.14$ & $0.49 \pm 0.20$ & $11.50 \pm 2.19$ & $47.53 \pm 14.55$ \\
\hline 22 & 19 & Šābuhr I & $241-272$ & & $\mathrm{HPbHSn}$ & $58.70 \pm 2.49$ & $0.14 \pm 0.02$ & $6.85 \pm 0.31$ & $33.60 \pm 2.79$ \\
\hline \multirow[t]{3}{*}{31} & 17 & Šābuhr I & $241-272$ & & $\mathrm{HPb}$ & $56.07 \pm 7.44$ & nd & $1.55 \pm 0.21$ & $41.48 \pm 7.20$ \\
\hline & $191^{\mathrm{a}}$ & Šābuhr I & $241-272$ & & $\mathrm{HPb}$ & 66.50 & 0.01 & 0.004 & 33.00 \\
\hline & $193^{\mathrm{a}}$ & Šābuhr I & $241-272$ & & & 82.90 & 0.05 & 2.66 & 13.90 \\
\hline 32 & 20 & Ohrmazd I & $270-271$ & & HPbHSn & $66.67 \pm 9.69$ & nd & $15.34 \pm 2.55$ & $17.43 \pm 7.04$ \\
\hline 33 & 21 & Wahrām I & $271-274$ & & $\mathrm{HPb}$ & $81.06 \pm 2.58$ & nd & $1.36 \pm 0.17$ & $16.63 \pm 2.69$ \\
\hline 42 & 28 & Šābuhr II & 309-379 & & $\mathrm{HPbHSn}$ & $54.35 \pm 5.49$ & nd & $5.43 \pm 1.05$ & $39.63 \pm 4.26$ \\
\hline 48 & 30 & Šābuhr II & 309-379 & & $\mathrm{HPb}$ & $60.49 \pm 12.27$ & $0.13 \pm 0.17$ & $1.26 \pm 0.22$ & $37.21 \pm 11.78$ \\
\hline 50 & 29 & Šābuhr II & 309-379 & & $\mathrm{HPb}$ & $75.78 \pm 11.88$ & nd & $2.90 \pm 0.24$ & $20.94 \pm 11.59$ \\
\hline 52 & 26 & Šābuhr II & $309-379$ & & $\mathrm{HPbHSn}$ & $75.98 \pm 7.78$ & bql & $7.53 \pm 0.90$ & $14.19 \pm 6.28$ \\
\hline 60 & 41 & Wahrām IV & 388-399 & & $\mathrm{AgPb}$ & $96.97 \pm 0.93$ & $0.74 \pm 0.01$ & bql & $1.72 \pm 0.80$ \\
\hline 64 & 47 & Yazdgerd I & $399-420$ & & $\mathrm{HPb}$ & $62.44 \pm 2.12$ & $1.40 \pm 0.29$ & $1.93 \pm 0.65$ & $33.81 \pm 2.24$ \\
\hline 67 & 76 & Wahrām V & $420-438$ & AY & & $93.09 \pm 0.57$ & $0.48 \pm 0.07$ & $1.89 \pm 0.01$ & $4.21 \pm 0.38$ \\
\hline 70 & 77 & Wahrām V & $420-438$ & WH & $\mathrm{HPb}$ & $58.90 \pm 4.88$ & $0.13 \pm 0.03$ & $2.14 \pm 0.26$ & $38.27 \pm 4.67$ \\
\hline 71 & 75 & Wahrām V & $420-438$ & WH & $\mathrm{HPb}$ & $73.38 \pm 7.74$ & $0.49 \pm 0.21$ & $2.86 \pm 0.77$ & $22.81 \pm 6.74$ \\
\hline 73 & 53 & Wahrām V & $420-438$ & & $\mathrm{HPb}$ & $78.29 \pm 8.71$ & nd & $0.82 \pm 0.06$ & $21.77 \pm 8.77$ \\
\hline 74 & 74 & Wahrām V & $420-438$ & "Eastern-Iran" & & $99.59 \pm 0.04$ & $0.07 \pm 0.01$ & nd & bql \\
\hline 75 & 51 & Wahrām V & $420-438$ & & & $91.93 \pm 3.04$ & $0.19 \pm 0.08$ & bql & $7.49 \pm 2.98$ \\
\hline 76 & 58 & Wahrām V & $420-438$ & & $\mathrm{HPb}$ & $69.30 \pm 7.72$ & $0.89 \pm 0.26$ & $1.03 \pm 0.07$ & $27.90 \pm 7.25$ \\
\hline 77 & 49 & Wahrām V & $420-438$ & & ACL & $99.65 \pm 0.31$ & $0.06 \pm 0.05$ & nd & bql \\
\hline 78 & 56 & Wahrām V & $420-438$ & & $\mathrm{HPb}$ & $84.42 \pm 13.83$ & $0.52 \pm 0.42$ & $1.04 \pm 0.07$ & $13.49 \pm 11.54$ \\
\hline 79 & 50 & Wahrām V & $420-438$ & & $\mathrm{HPb}$ & $76.78 \pm 8.7$ & $0.07 \pm 0.11$ & $2.79 \pm 0.29$ & $28.73 \pm 8.26$ \\
\hline 80 & 54 & Wahrām V & $420-438$ & & $\mathrm{HPb}$ & $56.99 \pm 7.09$ & $0.79 \pm 0.05$ & $4.30 \pm 0.06$ & $37.07 \pm 6.59$ \\
\hline 81 & 52 & Wahrām V & $420-438$ & "Eastern-Iran" & ACL & $99.69 \pm 0.05$ & bql & nd & bql \\
\hline 83 & 80 & Yazdgerd II & $438-457$ & AY & $\mathrm{AgPb}$ & $98.78 \pm 0.18$ & $0.25 \pm 0.03$ & nd & $0.71 \pm 0.16$ \\
\hline 84 & 69 & Yazdgerd II & $438-457$ & AY & & $94.46 \pm 0.25$ & $1.05 \pm 0.03$ & $1.10 \pm 0.04$ & $2.96 \pm 0.24$ \\
\hline 86 & 81 & Yazdgerd II & $438-457$ & WH & $\mathrm{HPb}$ & $87.64 \pm 3.13$ & $0.30 \pm 0.03$ & bql & $11.68 \pm 3.15$ \\
\hline 87 & 79 & Yazdgerd II & $438-457$ & WH & & $90.76 \pm 1.37$ & $0.82 \pm 0.06$ & $0.96 \pm 0.08$ & $6.92 \pm 1.25$ \\
\hline 88 & 65 & Yazdgerd II & $438-457$ & & $\mathrm{HPb}$ & $83.46 \pm 17.23$ & $0.11 \pm 0.18$ & $1.07 \pm 0.48$ & $14.95 \pm 16.86$ \\
\hline 90 & 70 & Yazdgerd II & $438-457$ & & & $90.12 \pm 2.27$ & $0.17 \pm 0.01$ & $0.50 \pm 0.02$ & $8.32 \pm 2.30$ \\
\hline 91 & 60 & Yazdgerd II & $438-457$ & & $\mathrm{HPb}$ & $73.63 \pm 1.56$ & $0.22 \pm 0.02$ & $1.34 \pm 0.35$ & $24.44 \pm 1.65$ \\
\hline 93 & 68 & Yazdgerd II & $438-457$ & & $\mathrm{HPb}$ & $75.08 \pm 8.88$ & $1.27 \pm 0.06$ & $1.40 \pm 0.23$ & $21.82 \pm 8.60$ \\
\hline 95 & 63 & Yazdgerd II & $438-457$ & & $\mathrm{AgPb}$ & $97.66 \pm 0.16$ & $0.26 \pm 0.03$ & $0.41 \pm 0.03$ & $1.32 \pm 0.14$ \\
\hline 96 & 67 & Yazdgerd II & $438-457$ & & & $91.91 \pm 1.53$ & $0.03 \pm 0.08$ & bql & $8.05 \pm 1.51$ \\
\hline 97 & 61 & Yazdgerd II & $438-457$ & & & $86.97 \pm 4.40$ & $0.68 \pm 0.03$ & $5.17 \pm 0.33$ & $6.64 \pm 4.08$ \\
\hline 99 & 71 & Pērōz & $457-484$ & AY & $\mathrm{HPb}$ & $83.74 \pm 6.00$ & $0.09 \pm 0.07$ & $1.42 \pm 0.27$ & $14.28 \pm 5.64$ \\
\hline 100 & 89 & Pērōz & $484-488$ & $\mathrm{AY}$ & & $89.81 \pm 1.84$ & $0.40 \pm 0.11$ & $0.70 \pm 0.03$ & $8.74 \pm 1.88$ \\
\hline 102 & 88 & Pērōz & $457-484$ & AY & HPbHSn & $58.37 \pm 2.14$ & $0.47 \pm 0.02$ & $6.82 \pm 0.39$ & $33.60 \pm 1.63$ \\
\hline 103 & 83 & Pērōz & $457-484$ & $\mathrm{GW}$ & $\mathrm{HPb}$ & $82.08 \pm 5.17$ & $0.78 \pm 0.00$ & $0.06 \pm 0.03$ & $16.73 \pm 5.15$ \\
\hline
\end{tabular}


Table 6 (continued)

\begin{tabular}{|c|c|c|c|c|c|c|c|c|c|}
\hline Cat. number & $\begin{array}{l}\text { RMAH- } \\
\text { number }\end{array}$ & King & Date & Mint/origin & $\begin{array}{l}\text { Chemical } \\
\text { group }\end{array}$ & $\mathrm{Cu}(\mathrm{wt} \%)$ & As (wt $\%)$ & Sn $(w t \%)$ & $\mathrm{Pb}(\mathrm{wt} \%)$ \\
\hline 106 & 90 & Pērōz & $457-484$ & & & $99.76 \pm 0.03$ & nd & nd & nd \\
\hline 107 & 87 & Pērōz & $457-484$ & & $\mathrm{HPbHSn}$ & $52.88 \pm 10.85$ & $0.26 \pm 0.10$ & $8.11 \pm 0.80$ & $38.36 \pm 9.95$ \\
\hline 109 & 94 & Walaxš & $484-488$ & & & $95.51 \pm 1.10$ & $0.53 \pm 0.09$ & bql & $3.49 \pm 0.99$ \\
\hline 110 & 93 & Walaxš & $484-488$ & AY & & $94.31 \pm 0.14$ & $1.75 \pm 0.14$ & nd & $3.60 \pm 0.01$ \\
\hline 111 & 122 & Kawād I & $488-496$ & ART & & $92.37 \pm 1.59$ & $2.20 \pm 0.44$ & bql & $4.92 \pm 1.17$ \\
\hline 112 & 110 & Kawād I & $488-496$ & ART & & $98.80 \pm 0.33$ & $0.96 \pm 0.34$ & nd & nd \\
\hline 113 & 117 & Kawād I & $488-496$ & AS & $\mathrm{ACL}$ & $99.39 \pm 0.08$ & $0.36 \pm 0.07$ & nd & nd \\
\hline 114 & 115 & Kawād I & $488-496$ & AS & & $96.91 \pm 0.31$ & $2.68 \pm 0.32$ & nd & nd \\
\hline 115 & 102 & Kawād I & $488-496$ & AS & & $97.49 \pm 0.81$ & $1.11 \pm 0.38$ & nd & $1.01 \pm 0.44$ \\
\hline 116 & 128 & Kawād I & $488-496$ & $\mathrm{AW}$ & & $98.91 \pm 0.08$ & $0.58 \pm 0.04$ & nd & bql \\
\hline 117 & 118 & Kawād I & $488-496$ & AW & & $97.80 \pm 0.99$ & $1.09 \pm 0.58$ & nd & $0.70 \pm 0.31$ \\
\hline 118 & 97 & Kawād I & $488-496$ & BYŠ & & $97.23 \pm 0.68$ & $0.42 \pm 0.15$ & $1.15 \pm 0.39$ & nd \\
\hline 119 & 99 & Kawād I & $488-496$ & BYŠ & $\mathrm{ACL}$ & $98.91 \pm 0.15$ & $0.40 \pm 0.02$ & $0.28 \pm 0.01$ & bql \\
\hline 120 & 126 & Kawād I & $488-496$ & BYŠ & & $91.38 \pm 0.70$ & $0.08 \pm 0.03$ & nd & $0.87 \pm 0.42$ \\
\hline 121 & 73 & Kawād I & $488-496$ & BYŠ & $\mathrm{ACL}$ & $99.15 \pm 0.06$ & $0.16 \pm 0.01$ & $1.00 \pm 0.02$ & nd \\
\hline 122 & 72 & Kawad I & $488-496$ & BYŠ & $\mathrm{ACL}$ & $97.31 \pm 0.40$ & $0.67 \pm 0.10$ & $0.16 \pm 0.12$ & $0.51 \pm 0.16$ \\
\hline 123 & 100 & Kawād I & $488-496$ & BYŠ & $\mathrm{ACL}$ & $99.55 \pm 0.01$ & $0.20 \pm 0.01$ & nd & nd \\
\hline 124 & 111 & Kawād I & $488-496$ & BYŠ & & $99.58 \pm 0.05$ & $0.14 \pm 0.02$ & nd & bql \\
\hline 125 & 114 & Kawād I & $488-496$ & BYŠ & $\mathrm{ACL}$ & $98.57 \pm 0.10$ & $1.17 \pm 0.11$ & nd & nd \\
\hline 126 & 98 & Kawād I & $488-496$ & BYŠ & $\mathrm{ACL}$ & $99.04 \pm 0.07$ & $0.72 \pm 0.05$ & nd & nd \\
\hline 127 & 113 & Kawād I & $488-496$ & BYŠ & & $96.47 \pm 0.26$ & $0.54 \pm 0.03$ & $1.14 \pm 0.08$ & $1.39 \pm 0.17$ \\
\hline 128 & 101 & Kawād I & $488-496$ & BYŠ & $\mathrm{ACL}$ & $99.11 \pm 0.05$ & $0.62 \pm 0.02$ & nd & nd \\
\hline 129 & 130 & Kawād I & $488-496$ & DA & & $94.72 \pm 1.08$ & $0.54 \pm 0.09$ & nd & $4.39 \pm 1.10$ \\
\hline 130 & 105 & Kawād I & $488-496$ & DA & $\mathrm{ACL}$ & $98.44 \pm 0.28$ & $1.31 \pm 0.27$ & nd & nd \\
\hline 131 & 135 & Kawād I & $488-496$ & GD & $\mathrm{ACL}$ & $99.37 \pm 0.04$ & $0.29 \pm 0.03$ & nd & nd \\
\hline 132 & 109 & Kawād I & $488-496$ & GW & $\mathrm{HPb}$ & $69.52 \pm 0.52$ & $0.35 \pm 0.12$ & $1.96 \pm 0.21$ & $27.68 \pm 0.36$ \\
\hline 133 & 103 & Kawād I & $488-496$ & GW & $\mathrm{ACL}$ & $98.99 \pm 0.36$ & $0.49 \pm 0.01$ & nd & bql \\
\hline 134 & 127 & Kawād I & $488-496$ & $\mathrm{KA}$ & & $93.92 \pm 3.24$ & $0.60 \pm 0.15$ & nd & $5.10 \pm 3.33$ \\
\hline 135 & 132 & Kawād I & $488-496$ & LD & $\mathrm{ACL}$ & $99.29 \pm 0.14$ & $0.21 \pm 0.00$ & bql & bql \\
\hline 136 & 112 & Kawād I & $488-496$ & LYW & & $98.87 \pm 0.56$ & $0.59 \pm 0.09$ & nd & bql \\
\hline 137 & 95 & Kawād I & $488-496$ & WH & & $95.19 \pm 0.39$ & $1.44 \pm 0.12$ & nd & $2.88 \pm 0.28$ \\
\hline 138 & 107 & Kawād I & $488-496$ & WH & & $92.69 \pm 1.19$ & $0.78 \pm 0.27$ & nd & $6.15 \pm 1.46$ \\
\hline 139 & 129 & Kawād I & $488-496$ & WH & & $97.43 \pm 0.44$ & $0.34 \pm 0.04$ & bql & $1.96 \pm 0.38$ \\
\hline 140 & 120 & Kawād I & $488-496$ & & & $93.85 \pm 0.81$ & $2.11 \pm 0.28$ & bql & $3.61 \pm 0.54$ \\
\hline 141 & 119 & Kawād I & $488-496$ & & & $84.50 \pm 6.92$ & $0.29 \pm 0.04$ & $0.70 \pm 0.12$ & $14.08 \pm 6.71$ \\
\hline 142 & 108 & Kawād I & $488-496$ & & & $99.73 \pm 1.12$ & $0.08 \pm 0.04$ & bql & nd \\
\hline 144 & 147 & Kawād I & $488-496$ & & & $94.37 \pm 0.64$ & $0.21 \pm 0.08$ & nd & $4.97 \pm 0.76$ \\
\hline 146 & 121 & Kawād I & $488-496$ & & $\mathrm{ACL}$ & $98.71 \pm 0.61$ & $0.97 \pm 0.03$ & nd & nd \\
\hline 147 & 96 & Kawād I & $488-496$ & & & $95.09 \pm 0.96$ & $0.34 \pm 0.05$ & $1.48 \pm 0.19$ & $2.61 \pm 0.73$ \\
\hline 148 & 131 & Kawād I & $488-496$ & & $\mathrm{ACL}$ & $99.34 \pm 0.01$ & $0.31 \pm 0.02$ & nd & bql \\
\hline 149 & 106 & Kawād I & $488-496$ & & $\mathrm{HPbHSn}$ & $54.87 \pm 1.72$ & $0.89 \pm 0.03$ & nd & $33.04 \pm 1.73$ \\
\hline 150 & 116 & Kawād I & $488-496$ & & $\mathrm{HPb}$ & $64.95 \pm 4.28$ & $0.96 \pm 0.09$ & $6.78 \pm 0.43$ & $26.50 \pm 4.18$ \\
\hline 151 & 104 & Kawād I & $488-496$ & & & $94.87 \pm 0.41$ & $1.57 \pm 0.16$ & nd & $3.22 \pm 0.27$ \\
\hline 152 & 124 & Kawād I & $488-496$ & & $\mathrm{HPb}$ & $75.27 \pm 5.43$ & $1.71 \pm 0.10$ & bql & $22.49 \pm 5.45$ \\
\hline 153 & 133 & Husraw I & $539-579$ & ART & $\mathrm{ACL}$ & $99.23 \pm 0.13$ & $0.46 \pm 0.11$ & nd & nd \\
\hline 154 & 134 & Husraw I & $539-579$ & AY & $\mathrm{ACL}$ & $99.13 \pm 0.07$ & $0.47 \pm 0.05$ & nd & bql \\
\hline 155 & 138 & Husraw I & $539-579$ & BYŠ & $\mathrm{ACL}$ & $98.24 \pm 0.03$ & $1.44 \pm 0.02$ & bql & nd \\
\hline 156 & 141 & Husraw I & $539-579$ & BYŠ & $\mathrm{ACL}$ & $98.73 \pm 0.19$ & $0.91 \pm 0.07$ & nd & bql \\
\hline
\end{tabular}


Table 6 (continued)

\begin{tabular}{|c|c|c|c|c|c|c|c|c|c|}
\hline Cat. number & $\begin{array}{l}\text { RMAH- } \\
\text { number }\end{array}$ & King & Date & Mint/origin & $\begin{array}{l}\text { Chemical } \\
\text { group }\end{array}$ & $\mathrm{Cu}(\mathrm{wt} \%)$ & As (wt\%) & Sn (wt $\%)$ & $\mathrm{Pb}(\mathrm{wt} \%)$ \\
\hline 157 & 139 & Husraw I & $539-579$ & BYŠ & ACL & $99.20 \pm 0.04$ & $0.52 \pm 0.05$ & nd & nd \\
\hline 158 & 143 & Husraw I & $539-579$ & DA & ACL & $99.16 \pm 0.26$ & $0.55 \pm 0.20$ & nd & nd \\
\hline 159 & 136 & Husraw I & $539-579$ & GD & ACL & $99.11 \pm 0.02$ & $0.55 \pm 0.05$ & nd & nd \\
\hline 160 & 144 & Husraw I & $539-579$ & GW & ACL & $99.45 \pm 0.11$ & $0.46 \pm 0.00$ & nd & bql \\
\hline 161 & 142 & Husraw I & $539-579$ & $\mathrm{GW}$ & $\mathrm{HPb}$ & $50.44 \pm 7.01$ & $2.92 \pm 0.40$ & nd & $46.18 \pm 6.77$ \\
\hline 162 & 145 & Husraw I & $539-579$ & ST & ACL & $99.23 \pm 0.03$ & $0.53 \pm 0.03$ & nd & nd \\
\hline 163 & 137 & Husraw I & $539-579$ & ST & ACL & $98.87 \pm 0.15$ & $0.75 \pm 0.10$ & nd & nd \\
\hline 164 & 140 & Husraw I & $539-579$ & & & $99.50 \pm 0.01$ & $0.26 \pm 0.08$ & nd & nd \\
\hline 165 & 146 & Husraw I & $539-579$ & & ACL & $96.28 \pm 0.02$ & $1.58 \pm 0.07$ & bql & $1.77 \pm 0.06$ \\
\hline 166 & 151 & Ohrmazd IV & $579-590$ & AW & ACL & $98.76 \pm 0.23$ & $0.68 \pm 0.15$ & nd & nd \\
\hline 167 & 149 & Ohrmazd IV & $579-590$ & ML & & $65.88 \pm 4.32$ & $0.64 \pm 0.01$ & nd & $33.05 \pm 4.32$ \\
\hline 168 & 148 & Ohrmazd IV & $579-590$ & ŠY & ACL & $99.11 \pm 0.04$ & $0.50 \pm 0.05$ & nd & nd \\
\hline 169 & 150 & Ohrmazd IV & $579-590$ & & & $99.68 \pm 0.01$ & nd & nd & nd \\
\hline 170 & 152 & Ohrmazd IV & $579-590$ & & ACL & $99.47 \pm 0.35$ & $0.11 \pm 0.00$ & nd & bql \\
\hline 173 & 155 & Wistahm & $591-595$ & LD & & $99.56 \pm 0.00$ & $0.06 \pm 0.00$ & bql & bql \\
\hline 175 & 156 & Husraw II & $591-628$ & $\mathrm{AW}$ & & $96.04 \pm 0.30$ & $0.61 \pm 0.08$ & $0.30 \pm 0.11$ & $2.32 \pm 0.26$ \\
\hline 176 & 158 & Husraw II & $591-628$ & $\mathrm{AW}$ & & $97.08 \pm 1.35$ & $0.29 \pm 0.01$ & $0.32 \pm 0.01$ & $1.60 \pm 1.12$ \\
\hline 177 & 160 & Husraw II & $591-628$ & BYŠ & ACL & $99.56 \pm 0.01$ & $0.06 \pm 0.02$ & bql & bql \\
\hline 178 & 163 & Husraw II & $591-628$ & BYŠ & ACL & $99.11 \pm 0.13$ & $0.64 \pm 0.09$ & nd & nd \\
\hline 184 & 166 & Husraw II & $591-628$ & & $\mathrm{AgPb}$ & $97.87 \pm 0.68$ & $1.55 \pm 0.28$ & nd & bql \\
\hline 185 & 161 & Husraw II & $591-628$ & & & $97.91 \pm 0.79$ & $0.76 \pm 0.19$ & $0.23 \pm 0.03$ & $0.73 \pm 0.57$ \\
\hline 186 & 159 & Husraw II & $591-628$ & & & $98.19 \pm 0.46$ & $0.53 \pm 0.01$ & nd & $0.95 \pm 0.49$ \\
\hline 187 & 162 & Husraw II & $591-628$ & & & $97.12 \pm 0.14$ & $0.18 \pm 0.01$ & $0.66 \pm 0.01$ & $1.67 \pm 0.14$ \\
\hline 188 & 165 & Husraw II & $591-628$ & & $\mathrm{AgPb}$ & $97.49 \pm 0.37$ & $1.54 \pm 0.30$ & nd & bql \\
\hline 189 & 164 & Husraw II & $591-628$ & & ACL & $99.48 \pm 0.36$ & $0.16 \pm 0.09$ & bql & bql \\
\hline \multirow[t]{13}{*}{190} & 169 & Yazdgerd III & $632-651$ & ST & & $98.20 \pm 0.15$ & $0.07 \pm 0.01$ & $1.35 \pm 0.06$ & nd \\
\hline & \multirow[t]{3}{*}{$31 X 7835.5 \mathrm{~A}$} & Measured & & & & $72.09 \pm 0.19$ & $0.17 \pm 0.01$ & $0.30 \pm 0.02$ & $3.67 \pm 0.18$ \\
\hline & & Reference & & & & $69.93 \pm 0.12$ & $0.148 \pm 0.00$ & $0.516 \pm 0.0007$ & $3.150 \pm 0.030$ \\
\hline & & $\%$ difference & & & & 3 & 15 & -42 & 17 \\
\hline & \multirow[t]{3}{*}{$32 X$ LB15 } & Measured & & & & $62.71 \pm 0.62$ & nd & $4.55 \pm 0.02$ & $21.38 \pm 0.29$ \\
\hline & & Reference & & & & $73.60 \pm 0.09$ & $0.027 \pm 0.001$ & $4.510 \pm 0.050$ & $21.420 \pm 0.140$ \\
\hline & & $\%$ difference & & & & -15 & & 1 & 0 \\
\hline & \multirow[t]{3}{*}{$31 X$ B26 } & Measured & & & & $61.67 \pm 0.30$ & nd & $1.62 \pm 0.03$ & $1.14 \pm 0.12$ \\
\hline & & Reference & & & & 63.20 & 0.120 & 1.400 & 0.950 \\
\hline & & $\%$ difference & & & & -2 & & 16 & 20 \\
\hline & \multirow[t]{3}{*}{$32 \mathrm{X}$ SN6 } & Measured & & & & $84.51 \pm 0.95$ & $0.79 \pm 0.02$ & $7.42 \pm 0.09$ & $0.94 \pm 0.08$ \\
\hline & & Reference & & & & $86.39 \pm 0.08$ & $0.764 \pm 0.006$ & $7.310 \pm 0.30$ & $1.559 \pm 0.015$ \\
\hline & & $\%$ difference & & & & -2 & 3 & 2 & -40 \\
\hline
\end{tabular}

natural presence of silver in the lead or due to the use of lead recovered from cupellation as alloying element. The best documented cupellation processes are those relating to the Roman period, where an ore containing as little as $400 \mathrm{ppm} \mathrm{Ag}$ would be considered a silver ore; typical silver levels in lead after cupellation are between 20 and $100 \mathrm{ppm}$ (Gomes et al. 2018 and references therein). As a rule then, silver contents in lead higher than $100 \mathrm{ppm}$, as observed here, are considered natural (Gomes et al. 2018). Similarly elevated Ag contents had already been observed in the lead coins of the same collection (Van Ham-Meert et al. 2018). We cannot discard of course that the real silver concentration might be lower due to surface enrichment of silver. 
Fig. 8 Histogram of the As content in samples from Pārs by mint (left) and by king (right)

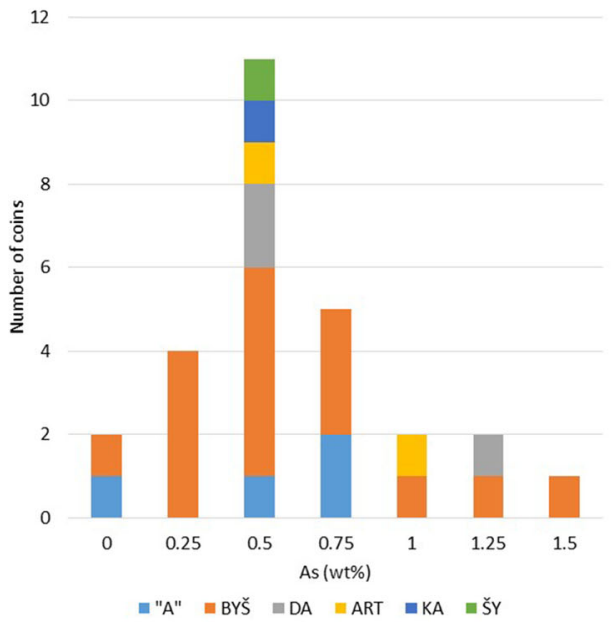

\section{Drahms}

After analysis, coins 28/12, 27/184, 24/185 and 25/187 were proven to be made of billon and not copper. Coin $28 / 12$ is slightly different; it is a silver coin debased with pewter instead of copper for the three other coins.

Coins $26 / 185$ and 23/182 are silver coins with $15 \mathrm{wt} \%$ leaded tin-bronze $23 / 182$ or pewter $24 / 185$; the addition of those alloying elements might be a form of debasing or a way of improving the hardness of the metal. Coins 27/184 and $24 / 185$ are made of copper with a few weight percent silver. In this collection (and in literature so far), the production of $\mathrm{Ag}-\mathrm{Cu}$ alloyed coins seems to stop after the reign of Wahrām I. One must be careful with this conclusion; however, as other collections, for which no compositional analysis has been performed, might equally contain coins erroneously labelled as copper or silver coins.

\section{Tin in coins}

According to Oudbashi et al. (2017), high tin bronzes are uncommon on the Iranian plateau before the Islamic period. A few examples exist: Iron Age tin bronzes from Luristan contain 2-11.5 wt\% tin (Oudbashi and Hasanpour 2018), one Sasanian vessel (or maybe more accurately a vessel in a style akin to the Sasanian style) with $37.55 \mathrm{wt} \%$ tin is reported. Oudbashi et al. (2017) further mention (without reference) that most Late Sasanian and early Islamic bronzes contain 20 to $22 \mathrm{wt} \%$ tin.

The concentrations of tin found for the coins in this work are lower than the compositions reported by Oudbashi for "Sasanian" tin bronzes. Furthermore, it should be kept in mind that due to corrosion the surface of the coins might be relatively enriched in tin (see "Limitations of surface analysis, a literature review" section). Contrary to the bronzes reported

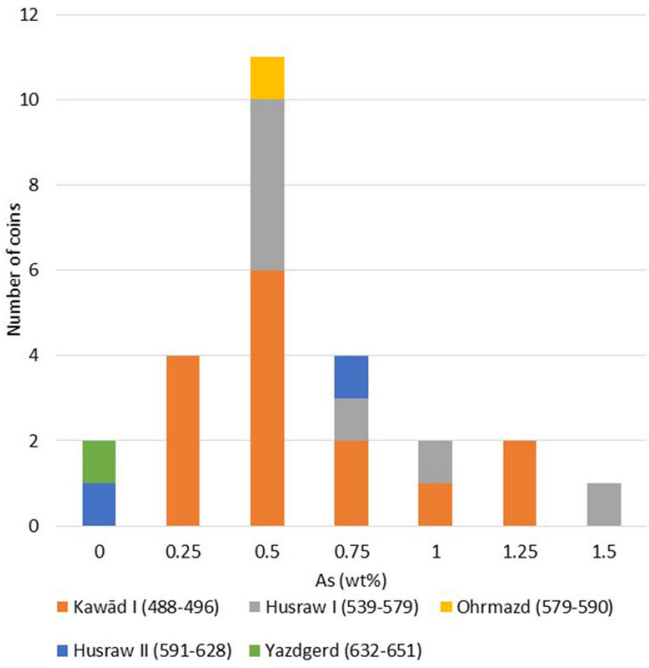

by Oudbashi et al. (2017), these are all leaded. Lead is often relatively enriched in the corrosion layer too; although reported lead concentrations may not be completely representative of the bulk composition, they still indicate the presence of lead in the coins. The lower tin contents encountered here, compared to the bronzes described by Oudbashi et al. (2017), and the presence of lead indicate that these alloys are part of a different alloying tradition.

The incidental or purposeful alloying with tin is a question worth exploring in this context. Tin is relatively rare and considered an important export product (Cuénod et al. 2015). At least two ancient mines in Iran are catalogued as $\mathrm{Cu}$-Sn mines by Nezafati et al. (2008): Deh Hosein (300 km south-west of Teheran) and Chah Palang (60 km south-east of Anarak). The minerals reported, however, are not mixed minerals but separate occurrences of cassiterite, native copper and copper oxides (Nezafati et al. 2008). Sasanians would have been able to distinguish these, making incidental alloying due to cosmelting unlikely. Incidental mixing through recycling practices is possible. Tin could also have been added for processing purposes as noted in the introduction, increasing fluidity.

\section{$\mathrm{Pb}$ in coins}

The presence of copper and bronze coins with large proportions of lead at the start of the Sasanian empire and its resurgence under Pērōz I mirrors the observations in the lead coin assemblage discussed by Van Ham-Meert et al. (2018). It was suggested that copper coins debased with lead finally gave rise to lead coins as a distinct type of coins with their own value at least from the reign of Šābuhr II onwards, and possibly before.

The continued existence of pure copper coins and the similarity in typology and colour between the pure copper and leaded copper coins suggests that both were used together and indiscriminately (i.e. leaded copper coins had the same value 
as copper coins) with many users unaware of there being two recipes in circulation. It is possible that the archaeological context in which the coins were found could provide a better image (leaded copper coins may have been used more extensively in certain parts of the empire). However, the absence of contextual data for these coins prevents such discussion. Coins are intrinsically objects that travel, which is also proven by the finds in Qasr-i Abu-Nasr, where coins struck in Dārābgird (DA), Staxr (ST) and Abād Bišābuhr were excavated (Blet-Lemarquand et al. 2014).

\section{Conclusion}

A total of 135 Sasanian copper and $\mathrm{Ag}-\mathrm{Cu}$ coins were analysed through $\mu \mathrm{XRF}$. The analysis confirmed that the early pure copper coins with large flan were mostly produced in Sakastān, whereas small pure copper coins came from different mints from Pārs, characterised by traces of arsenic. Coin $106 / 90$ is one exception of a small copper coin without arsenic. During the early stages of the Sasanian empire, next to the pure copper and billon coins, there are also coins with elevated lead and/or tin contents. Highly leaded copper coins are probably debased copper coins, used alongside the pure copper coins without the users being aware of the difference. The size of the coin determining its value, rather than its composition.

The presence of leaded bronze coins indicates that alloys for coinage were distinct from those for making objects as reported by, e.g. Oudbashi et al. 2017 for objects in the Sasanian style. An analysis of Sasanian bronze and copper objects would allow a better discussion of this.

In general, the composition of the copper coins is far less consistent than what was found for the lead coins. This can be either due to the size of the assemblage ( 5 times more copper than lead coins) or to a larger freedom of the mints in the production of these coins (both in terms of materials used and of alloy selection). The latter explanation seems unsatisfactory. To obtain a clearer view on the possible provenance of the coins, lead isotopic analysis will be performed on selected coins.

The silver content of silver tetradrahms is highly variable, which is somewhat unexpected considering the silver content determines the value. It is, however, completely in line with the compositional variety seen in copper coins.

The elemental analysis has further allowed to correct some mint attributions and to present the Sasanian copper coin production into the regional traditions.

Funding The research is funded by an FWO grant (G.0C43.15). The authors are grateful for the Hercules funding which allowed the purchase of the $\mu \mathrm{XRF}$.

\section{References}

Alram M (2007) Ardashir's eastern campaign and the numismatic evidence. Proc Br Acad 133:2-242. https://doi.org/10.5871/bacad/ 9780197263846.001 .0001

Alram M, Gyselen R (2003) Sylloge Nummorum Sasanidarum (Paris/ Berlin/Wien). Band I: Ardashir I.-Shapur II. Mit Beiträgen von P.O. Skjærvø, R. Linke, M. Schreiner, J.-N. Barrandon. Wien: Österreichische Akademie der Wissenschaften [Veröffentlichungen der numismatischen Kommission, Band 41]

Alram M, Gyselen R (2012) Sylloge Nummorum Sasanidarum (ParisBerlin-Wien). Band II: Ohrmazd I. - Ohrmazd II. Mit Beiträgen von M. Blet-Lemarquand, C.G. Cereti, R. Linke, M. Melcher, N. Schindel, M. Schreiner. Wien: Österreichische Akademie der Wissenschaften [Veröffentlichungen der numismatischen Kommission, Band 53]

Arafat A, Na'es M, Kantarelou V, Haddad N, Giakoumaki A, Argyropoulos V, Anglos D, Karydas A-G (2013) Combined in situ micro-XRF, LIBS and SEM-EDS analysis of base metal and corrosion products for Islamic copper alloyed artefacts from Umm Qais museum, Jordan. J Cult Herit 14:261-269

Bagheri H, Moore F, Alderton DHM (2007) Cu-Ni-Co-As (U) mineralization in the Anarak area of central Iran. J Asian Earth Sci 29: 651-665. https://doi.org/10.1016/j.jseaes.2006.03.011

Barrandon J (2003) Analyse des monnaies en alliage d'argent et de cuivre au centre Ernest Babelon d'Orléans. In: Alram M, Gyselen R (Ed). Sylloge Nummorum Sasanidarum (Paris-Berlin-Wien). Band I: Ardashir I.-Shapur I. Wien: Österreichische Akademie der Wissenschaften [Veröffentlichungen der numismatischen Kommission, Band 41], pp 88-90

Begemann F, Hauptmann A, Schmitt-Strecker S, Weisgerber G (2010) Lead isotope and chemical signature of copper from Oman and its occurrence in Mesopotamia and sites on the Arabian gulf coast. Arab Archaeol Epigr 21:135-169. https://doi.org/10.1111/j.16000471.2010.00327.x

Berthoud T, Cleuziou S, Hurtel LP, Menu M, Volfovsky C (1982) Cuivres et alliages en Iran, Afghanistan, Oman au cours des IVe et IIIe millénaires. Paléorient 8:39-54. https://doi.org/10.3406/paleo. 1982.4319

Birch T, Orfanou V, Lichtenberger A, Raja R, Barfod G, Lesher CE, Schulze I,Schulze W (2019) From nummi minimi to fulus - small change and wider issues: characterising coinage from Gerasa/Jerash (Late Roman to Umayyad periods). Archaeol Anthrop Sci 11:5359 5376

Blet-Lemarqand M (2012) L'apport des analyses élémentaires des monnaies de la collection de Paris. In: Alram M, Gyselen R (Ed). Sylloge Nummorum Sasanidarum (Paris-Berlin-Wien). Band II: Ohrmazd I.- Ohrmazd II. Wien: Österreichische Akademie der Wissenschaften [Veröffentlichungen der numismatischen Kommission, Band 53], pp 93-110

Blet-Lemarquand M, Gyselen R, Duval F (2014) Sur la composition élémentaire de quelques monnaies de cuivre Arabo-Sassanides. In: Gyselen R (Ed). Documents, Argenterie et monnaies de tradition Sassanide [Res Orientales. vol. XXII], Bures-sur-Yvette: Groupe pour l'Etude de la Civilisation du Moyen-Orient, pp 9-27

Bolewski A, Matosz M, Pohorecki W, del Hoyo-Meléndez JM (2020) Comparison of neutron activation analysis (NAA) and energy dispersive X-ray fluorescence (XRF) spectrometry for the nondestructive analysis of coins minted under the early Piast dynasty. Radiat Phys Chem 171. https://doi.org/10.1016/j.radphyschem. 2020.108699

Bollard I, Barrandon J-N (2006) Nouvelle contribution à l'étude du monnayage en bronze du IVe siècle après J.-C. Revue numismatique 162:277-310. https://doi.org/10.3406/numi.2006. 2811 
Constantinides I, Gritsch M, Adriaens A, Hutter H, Adams F (2001) Microstructural characterisation of five simulated archaeological copper alloys using light microscopy, scanning electron microscopy, energy dispersive $\mathrm{X}$-ray microanalysis and secondary ion mass spectrometry. Anal Chim Acta 440:189-198. https://doi.org/10. 1016/S0003-2670(01)01061-3

Craddock PT, Meeks ND (1987) Iron in ancient copper. Archaeometry 29:187-204. https://doi.org/10.1111/j.1475-4754.1987.tb00411.x

Crosera M, Baracchini E, Prenesti E, Giacomello A, Callegher B, Oliveri P, Adami G (2019) Elemental characterization of surface and bulk of copper-based coins from the Byzantine-period by means of spectroscopic techniques. Microchem J 147:422-428

Cuénod A, Bray P, Pollard AM, (2015) The "tin problem" in the prehistoric near east: Further insights from a study of chemical datasets on copper alloys from Iran and Mesopotamia. Iran 53:29-48. https:// doi.org/10.1080/05786967.2015.11834749

Delrue P (2008) Archaeometallurgical analyses of pre-Islamic artefacts from ed-Dur (Emirate of Umm al-Qaiwain, U.A.E.). PhD dissertation, Ghent University

Di Turo F, Coletti F, De Vito C (2020) Investigations on alloy-burial environment interaction of archaeological bronze coins. Microchem J 157:104882

Dussubieux L, Deraisme A, Frot G, Stevenson C, Creech A, Bienvenu Y (2008) LA-ICP-MS, SEM-EDS and EPMA analysis of Eastern North American copper-based artefacts: impact of corrosion and heterogeneity on the reliability of the LA-ICP-MS compositional results. Archaeometry 50:643-657. https://doi.org/10.1111/j.14754754.2007.00367.x

Epstein MS, Hendin DB, Lee LY, Bower NW (2010) Chemical attribution of corroded coins using X-ray fluorescence and lead isotope ratios: a case study from first century Judaea. Appl Spectrosc 64: 384-390. https://doi.org/10.1366/000370210791114211

Esposti MD, Renzi M, Rehren T (2016) Iron Age metallurgy at Salūt (Sultanate of Oman): a preliminary note (poster). Proc Sem Arab Stud 46:81-88

Fernandes R, van Os BJH, Huisman HDJ (2013) The use of Hand-Held $\mathrm{XRF}$ for investigating the composition and corrosion of Roman copper-alloyed artefacts. Herit Sci 1:1-7

Figueiredo E, Valério P, Araújo MF, Senna-Martinez JC (2007) MicroEDXRF surface analyses of a bronze spear head: lead content in metal and corrosion layers. Nucl Instrum Meth B 580:725-727. https://doi.org/10.1016/j.nima.2007.05.135

Gaudenzi Asinelli M, Martinón-Torres M (2016) Copper-alloy use in a Tyrrhenian medieval town: the case of Leopoli-Cencelle (Italy). J Archaeol Sci Rep 7:597-608. https://doi.org/10.1016/j.jasrep.2015. 09.023

Giardino C (2019) Early Iron Age, ca. 1300-300 BC. In: Giardino C (ed) Magan - the land of copper: prehistoric metallurgy of Oman. Archaeopress, Summertown, pp 114-138

Göbl R (1984) Münzprägung des Kūšānreiches, Wien

Gomes SS, Araújo MF, Monge Soares AM, Pimenta J, Mendes H (2018) Lead provenance of late Roman Republican artefacts from Monte dos Castelinhos archaeological site (Portugal): insights from elemental and isotopic characterization by Q-ICPMS. Microchem J 141:337-345. https://doi.org/10.1016/j.microc.2018.05.046

Gore DB, Davis G (2016) Suitability of transportable EDXRF for the onsite assessment of ancient silver coins and other silver artifacts. Appl Spectrosc 70:840-851

Gyselen R (2019) La géographie administrative de l'empire sassanide. Les témoignages épigraphiques en moyen-perse [Res Orientales, XXV], Bures-sur-Yvette: Groupe pour l'Étude de la Civilisation du Moyen-Orient

Gyselen R, Mochiri MI (2017) avec la collaboration de H. Hameeuw, Une Collection de monnaies sassanides de billon, de cuivre et de plomb. In: Gyselen R (Ed). Sasanian Coins, Middle-Persian Etymology and the Tabarestān Archive [Res Orientales, XXVI],
Bures-sur-Yvette:Groupe pour l'Étude de la Civilisation du Moyen-Orient, pp 9-106

Hajivaliei M, Khademi Nadooshan FK (2012) Compositional study of Parthian silver coins using PIXE technique. Nucl Instrum Meth B 289:56-58. https://doi.org/10.1016/j.nimb.2012.07.039

Hauptmann A, Weisgerber G (1980) The early bronze age copper metallurgy of Shahr-i-Sokhta Iran. Paléorient 6:120-123

Hauptmann A, Rehren T, Schmitt-Strecker S (2003) Early Bronze Age copper metallurgy at Shahr-i Sokhta (Iran), reconsidered. In: Stöllner T, Körlin G, Steffens G, Ćierny J (eds) Man and Mining (Mensch und Bergbau). Bochum, Deutsches Bergbau-Museum, pp 197-213

del Hoyo-Meléndez JM, Świt P, Matosz M, Woźniak M, KlisińskaKopacz A, Bratasz $Ł$ (2015) Micro-XRF analysis of silver coins from medieval Poland. Nucl Instrum Meth B 349:6-16. doi.org/10. 1016/j.nimb.2015.02.018

Inberg A, Ashkenazi D, Cohen M, Iddan N, Cvikel D (2018) Corrosion products and microstructure of copper alloy coins from the Byzantine-period Ma'agan Mikhael B shipwreck, Israel. Microchem J 143:400-409

Keturakis CJ, Notis B, Blenheim A, Miller AC, Pafchek R, Notis MR, Wachs IE (2016) Analysis of corrosion layers in ancient Roman silver coins with high resolution surface spectroscopic techniques. Appl Surf Sci 376:241-251

Linke R, Schreiner M (2003) Materialanalytische untersuchungen mittels energiedispersiver Röntgenfluoreszenzanalyse und energiedispersiver Röntgenmirkoanalyse im Rasterelektronenmikroskop. In: Alram M, Gyselen R (Ed). Sylloge Nummorum Sasanidarum (Paris-Berlin-Wien). Band I: Ardashir I.-Shapur I. Wien: Österreichische Akademie der Wissenschaften [Veröffentlichungen der numismatischen Kommission, Band 41], pp 70-87

Maddin R, Muhly JH, Stech-Wheeler T (1980) Research at the center for ancient metallurgy. Paléorient 6:111-119

Masjedi P, Khademi Nadooshan F, Hajivaliei M, Kouhpar SMM, Neystani J (2013) Elemental analysis of silver coins of Seljuk's' of Rome by PIXE: A case study. Mediter Archaeol Archaeom 13:181187

Mödlinger M, Cziegler A, Macció D, Schnideritsch H, Sabatini B (2018) Archaeological arsenical bronzes and equilibrium in the $\mathrm{As}-\mathrm{Cu}$ system. Metall Mater Trans B Process Metall Mater Process Sci 49: 2505-2513. https://doi.org/10.1007/s11663-018-1322-8

Mödlinger M, de Oro Calderon R, Haubner R (2019) Arsenic loss during metallurgical processing of arsenical bronze. Archaeol Anthropol Sci 11:133-140. https://doi.org/10.1007/s12520-017-0534-1

Momenzadeh M (2004) Metallic mineral resources of Iran, mined in ancient times. A brief review, In: Stöllner T, Slotta R, Vantandoust A (Ed). Persia's Ancient splendor (Persiens Antike Pracht): mining, handicraft and archaeology, Bochum, pp 8-21

Nezafati N, Pernicka E, Momenzadeh M (2008) Iranian ore deposits and their role in the development of ancient cultures. Anschnitt 21:7790

Notis M, Shugar A, Herman D, Ariel D (2007) Chemical composition of the Isfiya and Qumran coin hoards, In: Glascock M, Speakman RJ, Popelka-Filcoff RS (Ed). Archaeological chemistry: analytical techniques and archaeological interpretation, ACS Symposium Series 968; American Chemical Society: Washington, DC, pp 258-274

Orfanou V, Rehren T (2015) A (not so) dangerous method: pXRF vs. EPMA-WDS analyses of copper-based artefacts. Archaeol Anthropol Sci 7:387-397. https://doi.org/10.1007/s12520-0140198-Z

Oudbashi O, Hasanpour A (2018) Bronze alloy production during the Iron Age of Luristan: a multianalytical study on recently discovered bronze objects. Archaeol Anthropol Sci 10:1443-1458

Oudbashi O, Emami SM, Davami P (2012) Bronze in archaeology: a review of the archaeometallurgy of bronze in ancient Iran. In: 
Collini L (ed) Copper Alloys - Early Applications and Current Performance - Enhancing Processes. Rijeka, InTech, pp 153-178

Oudbashi O, Hasanpour A, Jahanpoor A, Rahjoo Z (2017) Microscopic and microanalytical study on Sasanian metal objects from western Iran: a case study. Sci Technol Archaeol Res 3:194-205. https://doi. org $/ 10.1080 / 20548923.2017 .1384175$

Oudbashi O, Mehofer M, Basafa H, Tayyari J, Bahadori S (2020) Arsenical copper and bronze metallurgy during Late Bronze Ageof north-eastern Iran: evidences fromShahrak-e Firouzeharchaeological site. Archaeol anthrop Sci: 12. https://doi. org/10.1007/s12520-020-01182-3

Pigott VC (1980) Research at MASCA. Paléorient 6:105-110

Rehren T, Boscher L, Pernicka E (2012) Large scale smelting of speiss and arsenical copper at Early Bronze Age Arisman, Iran. J Archaeol Sci 39:1717-1727

Robotti S, Rizzi P, Soffritti C, Garagnani GL, Greco C, Facchetti F, Borla M, Operti L, Agostino A (2018) Reliability of portable X-ray fluorescence for the chemical characterisation of ancient corroded copper-tin alloys. Spectrochim Acta B At Spectrosc 146:41-49

Schindel N (2004) Sylloge Nummorum Sasanidarum (Paris - Berlin Wien). Band III: Shapur II. - Kawad I./2 Regierung, 2 vol., Wien, 2004. In: Schindel N (Ed). Sylloge Nummorum Sasanidarum (ParisBerlin-Wien). Band III:/1 Shapur II.-Kawad I./ 2. Regierung. Wien: Österreichische Akademie der Wissenschaften

Schindel N (2015) Sakastan in the fourth and fifth century AD. some historical remarks based on the numismatic evidence. Electrum 22: 227-248. https://doi.org/10.4467/20800909EL.15.012.3950
Schindel N (2016) A new look at the Thronfolgerprägungen of the Sasanian king Ardashir: Goodbye to Shapur I, welcome to Ardashir Sakanshah. Numis Chron 179:227-240 pl. 27

Shavarebi E (2017) Sakastān in der frühen Sasanidenzeit: Münzprägung und Geschichte In: Olbrycht MJ (Ed). Anabasis, 8, Collectanea Iranica et Asiatica. Iran and Western Asia in Antiquity. New Perspectives, pp 160-177

Shugar AN (2013) Portable X-ray fluorescence and archaeology: limitations of the instrument and suggested methods to achieve desired results. In: Armitage RA, Burton JH (eds) Archaeological Chemistry VIII. American Chemical Society, Washington, DC, pp 173-193

Thornton CP, Lamberg-Karlovsky CC, Liezers M, Young SMM (2002) On pins and needles: Tracing the evolution of copper-base alloying at Tepe Yahya, Iran, via ICP-MS analysis of common-place Items. J Archaeol Sci 29:1451-1460

Tylecote RF, Ghaznavi HA, Boydell PJ (1977) Partitioning of trace elements between the ores, fluxes, slags and metal during the smelting of copper. J Archaeol Sci 4:305-333. https://doi.org/10.1016/03054403(77)90027-9

Van Ham-Meert A, Rademakers FW, Claeys P, Gurnet F, Gyselen R, Overlaet B, Degryse P (2018) Novel analytical protocols for elemental and isotopic analysis of lead coins - Sasanian lead coins as a case study. Archaeol Anthropol Sci 11:3375-3388. https://doi.org/ 10.1007/s12520-018-0758-8

Publisher's note Springer Nature remains neutral with regard to jurisdictional claims in published maps and institutional affiliations. 